\title{
Understanding the specific nature of the East Asia Neolithic transition
}

\author{
Oksana Yanshina \\ Peter the Great Museum of Anthropology and Ethnography of Russian Academy of Sciences, Sankt Peterburg, RU \\ oyanshina@mail.ru
}

\begin{abstract}
The main subject of this article is to define the specific nature of the Palaeolithic-Neolithic transition in East Asia. A comparative analysis of regional East Asian data was run in order to achieve this. As a result, three dissimilar models of the Neolithic transition were distinguished: MesoNeolithic, Subneolithic, and Neolithic proper. The first and last are similar to their counterparts in the western part of Eurasia, but the Subneolithic is unique for East Asia. Regarding chronology, two stages of Neolithic transition can be clearly recognized in this region. The new Subneolithic type of hunter-gatherer cultures occurred during the first stage around the Sea of Japan. At the second stage, the transition to food production started in central and north-central China. In between, there was a cultural, spatial and temporal gap splitting up the transitional process into two isolated episodes.
\end{abstract}

KEY WORDS - East Asia; Palaeolithic-Neolithic transition; Neolithic; Subneolithic; Meso-Neolithic; origin of pottery

\section{Razumevanje posebne narave prehoda v neolitik na območju Vzhodne Azije}

IZVLEČEK - V članku razpravljamo o posebni naravi prehoda med paleolitikom in neolitikom na območju Vzhodne Azije. Pri tem smo si pomagali s primerjalno analizo podatkov, pridobljenih na tem območju. Kot rezultat predstavljamo tri različne modele prehoda v neolitik: mezo-neolitik, pod-neolitik in pravi neolitik. Prvi in zadnji sta podobna procesom v zahodnem delu Evrazije, medtem ko je pod-neolitik pojav, značilen le za Vzhodno Azijo. Tukaj lahko na podlagi kronologije jasno razločimo dve stopnji prehoda $v$ neolitik. Sprva se je nova oblika pod-neolitika oblikovala med lovci in nabiralci na območju Japonskega morja. V drugi stopnji pa se začne pridelava hrane na območju osrednje in na severnem delu osrednje Kitajske. Med obema stopnjama je kulturna, prostorska in časovna prekinitev, ki proces prehoda $v$ neolitik deli na dva ločena pojava.

KLJUČNE BESEDE - Vzhodna Azija; prehod paleolitik-neolitik; pod-neolitik; mezo-neolitik; izvor lončenine

\section{Introduction}

Recent discoveries provide increasing evidence that many human achievements, previously consid-ered to be a product of the Neolithic agrarian revolution, were made before it happened (Barnett, Hoppes 1995; Roosevelt 1995; Close 1995; Rice 1999; Jesse 2003; Keally et al. 2003; Kuzmin 2006; 2010;
2015; Budja 2006; 2016; Jordan, Zvelebil 2009; Huyseco et al. 2009, Hommel 2012; Gibbs, Jordan 2013; Cohen 2013; 2017). A huge number of studies have been made to explain the new facts and link them with the traditional point of view, and as a result a new paradigm began to take a shape in 
the literature, radically changing our understanding of the Neolithic (Zeder 2009; 2011; Fuller et al. 2011; Finlayson 2013; Özdoğan 2010; 2014; Uchiyama et al. 2014; Nordqvist, Kriiska 2015; Gibbs, Jordan 2016). Two statements constitute its core. One of them postulates the multiplicity of the Neolithic forms and their ways of evolving, whereas the second call into question the revolutionary nature of the Neolithisation, since new data indicate that this process was protracted and not as influential as previously considered.

It should be noted these new views are coming rapidly into ascendance, and are recurrently ex-pressed by different scholars and with different rationales. It seems that right now a new Neolithic concept is being formed. Accordingly, the Neolithic turns from a global phenomenon with a single set of innovations into some kind of 'patchwork' phenomenon consisting of many different regional forms. In this vision, the long polycentric process of Neolithic development substitutes the Neolithic burst in a core area with subsequent transmission of the readymade package of Neolithic innovations beyond its borders.

It is quite understandable that the new perspectives are based to a large extent on data from East Asia, as the Neolithic transition began there with the advent of pottery and ended with the develop-ment of agriculture, while in West Asia, providing a classic case of Neolithic research, this sequence was reversed (Björk 1998; Bar-Yozef 2011a; Kuzmin 2013; Gibbs 2015; Gibbs, Jordan 2016; Fuller, Stevens 2017). This indicates a clear discrepancy between the eastern and western pathways of the Neolithic transition. However, does this observation cover all features separating East and West Asia? In this paper, I will attempt to summarize the data concerning this question. My analysis shows that spatio-temporal dynamics of the Neolithic transition and its regional differences also deserve our attention from this point of view.

However, before starting, some preliminary remarks have to be made with regard to the terms and approaches taken in this study. In a broad sense, the Neolithic transition means people's shift from the Palaeolithic to Neolithic way of life. But the understanding of the latter has been changing drastically in recent years. Nowadays the question of what was the endpoint of this process thus arises in almost every research lying in the scope of Neolithic studies. The traditional point of view takes agriculture as the terminus of the Neolithic transition, while another widespread position sees pottery as the endpoint. However, the concept of the multifarious Neolithic seems to infer that there is no one proper answer to this question.

In the present study, I would prefer to avoid the generalizations that hide beneath the question above. First, in my opinion, we have to document and comprehend all possible regional variants of the Neolithic. Therefore, my task here is only to explore what is, in fact, the Neolithic transition in East Asia. However, even in this case it is necessary to define this process at least to outline the dataset relevant to this task. In this way, I propose to abide by the local schemes of interpreting the Neolithic. From this, the Neolithic transition is considered here as moving from what local researchers regard as its starting point to what they understand under the term Neolithic.

It also has to be added that East Asia is extremely extensive and diverse in both cultural and climatic terms. For this reason, in order to make out the shared features of the Neolithic transition in this vast area it is necessary first to define its regional peculiarities. My analysis shows three regional models of the Neolithic transition can be clearly recognized in East Asia: the Subneolithic in the Sea of Japan area, the Neolithic proper in central and northcentral China, and the Meso-Neolithic in the CircumBaikal region. Other territories did not generate any special forms of the Neolithic transition and might be characterized as laggards in this context (Eerkens, Lipo 2014).

Thus, further in this article regional data will be first presented so that they reflect a general sequence of the Neolithic transition in each of the three areas mentioned, and then an attempt to designate a region-wide scheme will be made. Finally, the assessment of this scheme will be done in comparison with the general pattern of the Neolithic transition according to its classical understanding registered in West Asia and implied the shift to farming.

\section{Regions around the Sea of Japan}

The Sea of Japan basin introduces the first model which is related to forming sedentary hunter-gatherer-fisher cultures, and therefore it can be defined as Subneolithic. A wide range of innovations emerged here during the course of the Neolithic transition. A little later, they will constitute the hallmark 

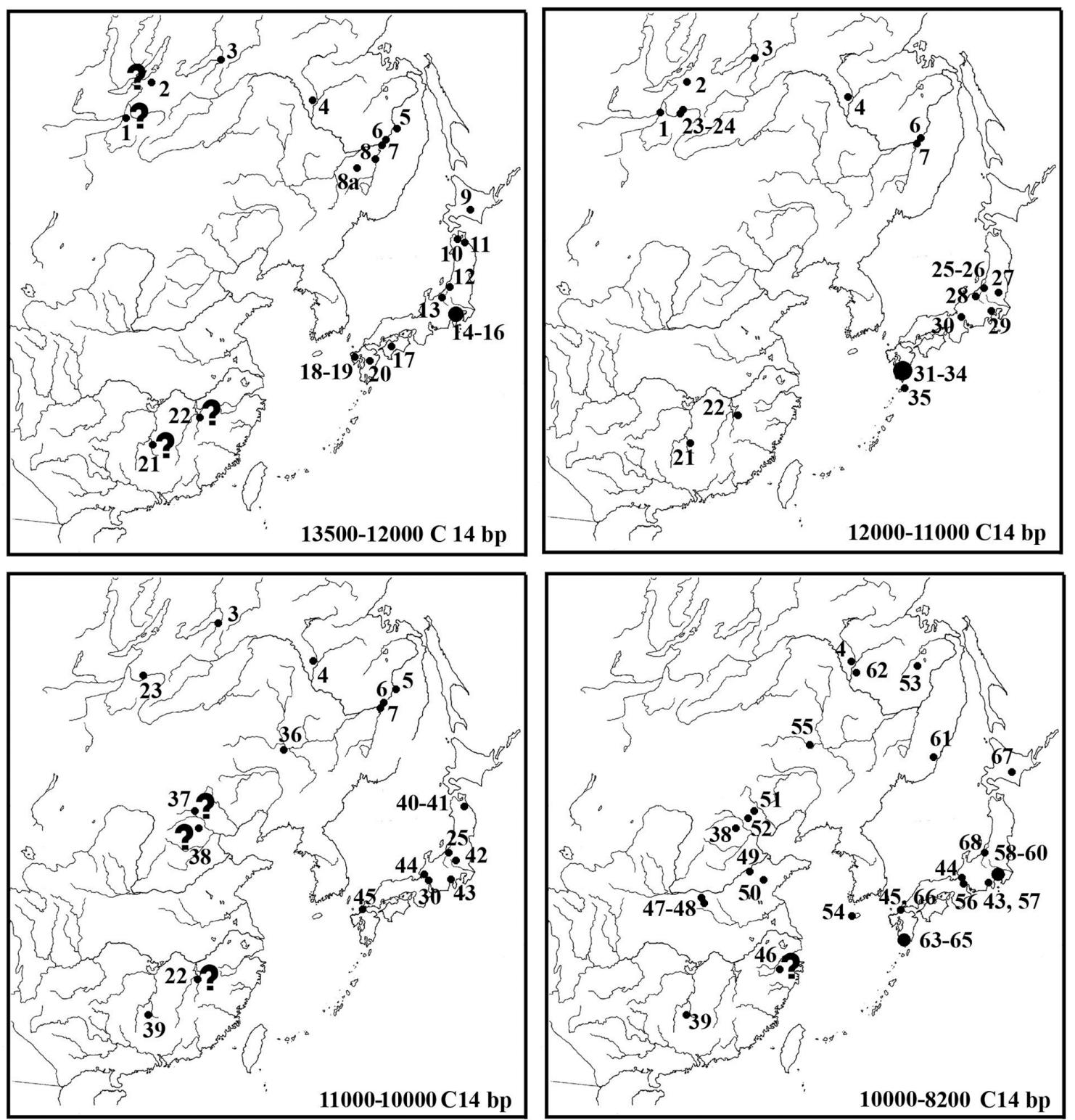

1 - Ust'-Kyakhta-3; 2 - Krasnaya Gorka; 3 - Ust'Karenga; 4 - Gromatukha; 5 - Khummi; 6 - Gasya; 7 - Goncharka-1, Novotroitskoe-10, Osinovaya Rechka-10, 16; 8 - Xiaonanshan; 8a - Taoshan; 9 - Taiso-3; 10 - Oday-Yamamoto-1; 11 - Kiwada; 12 - Kubodera-Minami; 13 - Seiko-Sanso; 14 - Gotenyama; 15 - Tsukumino-Kamino-2; 16 - Manpukuji; 17 - Kamikoroiwa; 18 - Fukui; 19 - Senpukuji; 20 - Kawayo F; 21 - Yuchanyan; 22 - Xianrengdong; 23 - Studyonoe-1; 24 - Ust'-Menza-1; 25 - Unoki-Minami; 26 - Jin; 27 - Nozawa; 28 - Nakamachi; 29 - SFS; 30 - Aitani-kumahara; 31 - Tsukabaru; 32 - Sojiyama; 33 - Shikazegashira; 34 - Higashi-Kurotsuchida; 35 - Sankakuyama-1; 36 - Houtaomuga; 37 - Yujiagou; 38 - Nanzhuangtou; 39 - Zengpiyan; 40 - Kushibiki; 41 - Takihata; 42 - Saishikada-Nakajima; 43 - Kuzuharazawa-4; 44 - Torihama; 45 - Obaru D; 46 - Shangshan; 47 - Lingjing; 48 - Lijiagou; 49 - Zhangmatun; 50 - Bianbiandong; 51 - Zhuannian; 52 - Donghulin; 53 - Yamikhta; 54 - Gosanri; 55 - Shuangta; 56 - Awazu-kotoi; 57 - Ikeda B; 58 - Hanawadai; 59 - Natsusima; 60 - Musashidai; 61 - Ustinovka-3; 62 - Chernigovka-na-Zee; 63 - Kakuriyama; 64 - Nagasakohira; 65 - Kivaki; 66 - Matsukida; 67 - Taiso-6; 68 - Kurohime

Fig. 1. Spatio-temporal distribution of pottery-bearing sites during the Neolithic transition (based on ${ }^{14} \mathrm{C}$ dates run on charcoal, bone or pottery charred crust). In the Japanese archipelago only the main sites have been marked due to their immense number.

of the 'northern' Neolithic and partly of the agrarian one. Three phases can be traced in the development of this scenario of the Neolithic transition.

The first phase is marked out by the sudden emergence of just three cultures of an absolutely new type: Incipient Jomon in the Japanese archipelago,
Osipovka culture in the Low Amur River, and the Gromatukha culture in the Middle Amur River (Fig. 1). Even the very first sites differed significantly from the surrounding Upper Palaeolithic ones, but over time these differences became more and more pronounced, and to the end of this phase the whole suite of Neolithic novelties was already engendered. 
The data from the Japanese archipelago, which is the most studied of all three areas examined in this paper, shows in detail the course of the Neolithic transition during this phase (Keally 1991; Kenrick 1995; Imamura 1996; Mizoguchi 2002; Sato, Tsutsumi 2002; Keally et al. 2003; Habu 2004; Kobayashi 2004; Pearson 2006; Kanner 2009; National Museum of Japanese History 2009; Kanomata 2010; Nakazawa et al. 2011; Sato et al. 2011; Nishida 2002; Kudo, Kumon 2012; Craig et al. 2013; Morisaki, Sato 2014; Seguchi 2014; Morisaki et al. 2015; Lucquin et al. 2016; Sato, Natsuki 2017; Morisaki, Natsuki 2017; Otsuka 2017; Ikawa-Smith 2017; Kanner, Taniguchi 2017; Morisaki et al. 2018).

The new type of sites came into existence on the north of the Paleo-Honshu Island just before the Bølling-Allerød warming. Soon after, the fast proliferation and at the same time enhancement of the new culture began. During this process, the highly evolved toolkit arose looking rather precocious or outpacing the time. It includes pottery, the rejection of microblade techniques in favour of a less demanding flake industry, the rejection of composite tools and shift to simple stone tools with facial secondary processing, partly polished axes and adzes, bifacial tools used as spearheads and arrowheads, new types of cutting and scraping tools, and abraders.

The appearance of this package of novelties took place against the background of changes in subsistence strategies and in a way of life as a whole, but in this field the transition did not keep up such a fast pace. At the current stage of knowledge, relocation of residential camps to the margins of rivers or lakes, reducing the dependence on stone raw materials of high quality, thickening of cultural depositions, expansion of social networks, and to some extent ascending the ritual behavior scale indicate these changes and signalize the outset of sedentarization process and moving to a broader economy.

The next set of novelties appeared a bit later during the Allerød warming on the southern part of modern Kyushu. Here, in more favourable climatic conditions, plant gathering, mainly of acorns, became a focus for local people (Habu 2004; Shibutani 2009; 2011; Kudo 2014; 2015; Noshiro et al. 2016). In addition, grinding tools, storage pits, semi-subterranean dwellings, and village-like settlements occurred for the first time here (Imamura 1996; Habu 2004; Shinto 2006; Pearson 2006; Morisaki, Sato 2014; Izuka, Izuho 2017; Morisaki et al. 2018).
It should be noted also that the process of Neolithisation was to a certain extent geographically uneven in the Japanese archipelago. The first Incipient Jomon sites arose on the North of Honshu, i.e. on the periphery of areas that were the most mastered by people developing the microblade industries. Moreover, where the microblade industries occurred earlier and evolved more than elsewhere, they persisted the longest. For example, on Hokkaido, the local people refused to adopt pottery and many other innovative changes during this phase, while on the south of Kyushu they conserved only microblade techniques. Moreover, on Hokkaido, and during this phase, the local people refused to adopt pottery and other innovative changes, while on the south of Kyushu people conserved only microblade techniques for a long term.

The archaeological data from the Amur River does not contradict these observations (Derevyanko, Medvedev 1995; 2006; Lapshina 1999; Kuzmin 2003; 2005; Kuzmin, Shewkomud 2003; Shewkomud, Yanshina 2010a; 2010b; 2012; Yanshina 2008; 2014). The Osipovsky sites appeared suddenly at the very outset of the Bølling-Allerød warming, and within an area which was not settled at all before. All of them were tied to the mainstream of the Amur River whose water level was $10 \mathrm{~m}$ higher at that time than today. To the end of the development of the Osipovka culture, we can see semi-subterranean household structures (like pits with unknown purposes, postholes, fireplaces, and possibly dwellings), stationary and portable ritual objects, signs of longterm habitation (e.g., palimpsests of settlement structures), and well established tool assemblages which include pottery and steady series of polished axes, bifacial spearheads and arrowheads, the new types of cutting and scraping tools, and abraders. Unfortunately, the timeline and scope of variety of the Gromatukha culture are poorly studied.

It should be added that throughout the first phase the traditional Upper Palaeolithic cultures continued to develop around of Sea of Japan, but occupying the other areas. Thus, they are known not only in Hokkaido but also in Sakhalin, Primorye, and Korea. Then over time, some of the novelties began to penetrate there, as mainly represented by arrowheads and axes (Vasil'yevsky et al. 1997; Kajiwara, Kononenko 1999; Cohen 2003; Vasilevsky 2008; Bae 2010; 2017; Otsuka 2017).

The second phase (10000-8000 14C bp) coincided with the first two or one and half millennia of the 
Holocene. It started with the more or less rapid disappearance of three pioneering cultures of the previous phase, though this process was also uneven throughout the region.

On the south of the Japanese archipelago it started slightly earlier under the impact of the Younger Dryas cooling (Nakazawa et al. 2011; Morisaki, Natsuki 2017). The Incipient Jomon camps totally disappeared here during this climatic event. At the same time, to the north, it seems this cooling had not such a damaging influence. On Honshu the number of sites reduced sharply but the Incipient Jomon culture survived, and on this basis the subsequent variants of Jomon culture were formed to further evolve the preceding achievements. During this phase, plant gathering and dwelling pits spread across all Paleo-Honshu while remaining rare. In addition, shell mounds and special fishing equipment (fishhooks, net weights, etc.) appeared for the first time at this phase, signalling the final establishment of the new subsistence strategies. However, there were no indications of the previous dynamism.

In the more northern areas, on the contrary, the Younger Dryas cooling coincided with the flourishing of the Osipovka culture occurred at the middle stage of its development. But with the onset of the Holocene, the Gromatukha and Osipovka cultures vanished, leaving no traces (Shewkomud, Yanshina 2012.231-244). The latest dates of the former vary within $9680 \pm 80$ and $9150 \pm 8014 \mathrm{C} \mathrm{bp} \mathrm{(Derevianko}$ et al. 2017); the latest dates of the latter are $9810 \pm$ 80 and $9430 \pm 70{ }^{14} \mathrm{C}$ bp (Fukuda et al. 2014) (Fig. 2 ). Thereafter and somewhere concurrently, a very pronounced gap in the archaeological records occurred along the Amur River and also in Sakhalin, Hokkaido, Primorye, and Korea with only a few exceptions: Ustinovka-3 in Primorye (Garkovik 1996; Derevyanko, Tabarev 2006), Yamikhta in the northeast part of the Amur River region (Fukuda et al. 2014), and Taiso-6 in Hokkaido (Obihiro City Board of Education 2005). Therefore, it is not known how the subsequent events developed in this area as a whole.

The third phase (8000-5500 ${ }^{14} \mathrm{C} \mathrm{bp)} \mathrm{comes} \mathrm{with} \mathrm{ap-}$ pearance across all the given area the fully-developed Neolithic sites or rather Subneolithic (Japan: Habu 2004; Imamura 1996; Nishida 2002; Matsumoto et al. 2017; Morisaki et al. 2018; Amur river: Derevyanko, Medvedev 2006; Shewkomud, Kuzmin 2009; Shewkomud, Yanshina 2012.31-244; Primorye: Andreeva 1991; Dyakov 1992; Zhushchikhov- skaya 2006; Batarshev 2009; Sakhalin: Grishchenko 2011; Vasilevsky, Shubina 2006; Kuzmin et al. 2012; see also Kuzmin 2005). These inherit the whole set of innovations developed earlier by the groups of Osipovka, Gromatukha, and Incipient Jomon cultures, but differ by the presence of a more pronounced ritual activity, including a regular burial practice, though not in all areas, as well as larger settlements with semi-subterranean dwellings. Subsistence practices become more developed and steady. According to the Japanese data, the economy acquires a complex nature, which makes it possible to efficiently exploit different seasonal resources without permanent residential movement. The shift to food production occurs here many millennia later, in each of the areas at a different time and in a different mode.

\section{Circum-Baikal region}

The Circum-Baikal region represents the second model and demonstrates one more way of forming a new type of hunter-gatherer-fisher cultures. Like in the previous case, this process can also be split into several phases. However, some general remarks have to be made before proceeding to describe them in detail.

First, the Baikal region is the only in East Asia where the presence of ceramics in the Late Pleistocene assemblages is still disputed. This greatly complicates an understanding of the general pattern of Neolithic transition in this area. It is not possible to characterize all of the controversial points of this discussion, since they can be found in various publications (Konstantinov 1994; 2009; Razgil'deeva et al. 2010; Vetrov 2010; Hommel 2012; Hommel et al. 2017).

Secondly, the Neolithic transition in the given area ran with some important differences between two opposite sides of Lake Baikal, i.e. Transbaikalia and Gisbaikalia. In the former, during the last millennia of the Pleistocene, the steady and continuous development of human culture is recorded up to the Holocene (Konstantinov 1994; Buvit et al. 2010), whereas in the latter there was a deep recession in the development reflected in a total reduction in the number of sites up to their complete disappearance (Berdnikova 2012). The situation, however, changed drastically with the onset of the Holocene. ${ }^{14 C}$ dated sites vanished in Transbaikalia (Konstantinov et al. 2016; see also Buvit et al. 2016), but in contrast the powerful Mesolithic culture arose in Gisbaikalia 


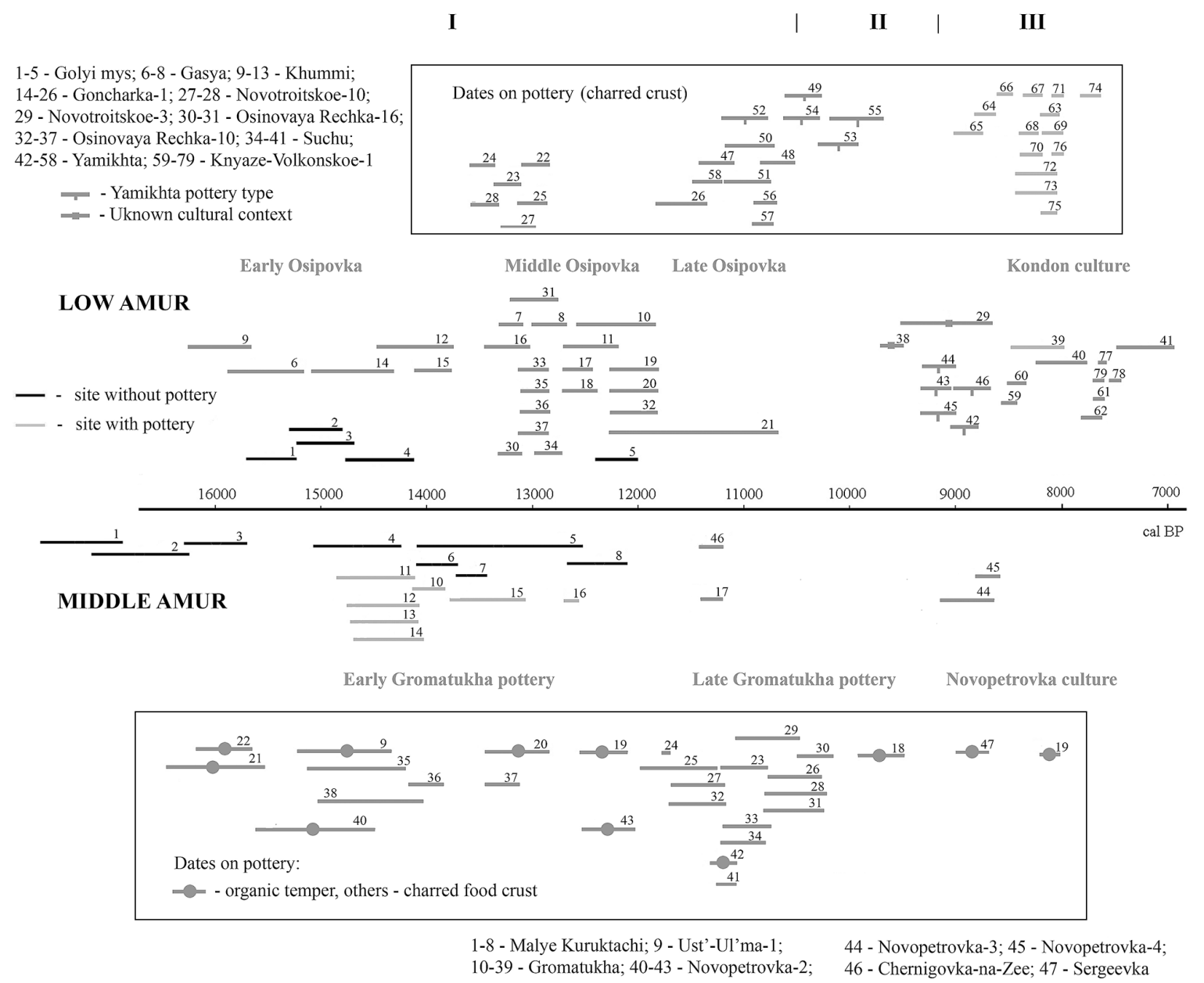

Fig. 2. Schematic representation of the Amur River radiocarbon date database referring to the Palaeolithic-Neolithic transition. Note the gap between the dates of the Gromatukha-Osipovka and the Neolithic site and differences between dates for the charcoal, organic temper, and food crust.

(Berdnikova et al. 2014; Losey, Nomokonova 2017). Due to this feature, the overall picture of the Neolithic transition can be comprehended only if both sides of Lake Baikal will be taken into consideration, though the early pottery is known only in the Transbaikalia, that normally falls into the focus of East Asia Neolithic studies (Fig. 1).

Thirdly, there is increasing evidence the territory adjacent to Lake Baikal was the easternmost point of the influence of the European Upper Palaeolithic (dwelling constructions, anthropomorphous and zoomorphic figurines, burials, etc.). It is interesting in this context that this area, in addition, is the only in East Asia where a Mesolithic period very similar to the European one is clearly distinguished (Kol'tsov 1989; Konstantinov 1994). The characteristic of this period is the new type of hunter-gatherer-fisher cultures forming at the interstice between the Upper Palaeolithic and the appearance of pottery. These cultures evolved toward the Neolithic quite slowly, holding many Upper Palaeolithic traits and adapt- ing incrementally to new environments and a more mobile way of life. Therefore, this model of the transition to the Neolithic can be labelled under the banner of Meso-Neolithic.

The first phase (12 700-10300 $\left.{ }^{14} \mathrm{C} \mathrm{bp}\right)$ started with the appearance of pottery in Transbaikalia (Kuzmin, Vetrov 2007; Razgil'deeva et al. 2013; Tsydenova et al. 2017). It occurred in the assemblages with the microblade industries represented by two traditions based on edge-shaped and wedge-shaped microcores (Tashak 2005; Tabarev, Gladyshev 2012; Pavlenok 2015; Tsydenova, Piezonka 2015). The former is called Selenginskaya, and it is considered to be local in origin. The overwhelming majority of sites located in the south of Transbaikalia are attributed to this tradition, and these are concentrated within the Selenga and Chikoy river systems. The second tradition is known as Chikoiskaya, and its origins have yet to be established, with sites mainly in the north of Transbaikalia (see exception: Moroz 2014a). 
Looking at the data as a whole, one can see in Transbaikalia a rather sharp rise in the total number of archaeological sites coinciding with this phase $(\mathrm{Bu}$ vit et al. 2016.Fig. 2). From this point of view, it looks like a single episode in the prehistory of this area. The shared trends in cultural development throughout this time also confirm this proposal, as outlined below.

Firstly, a very sophisticated house-building practice known from the earlier Upper Palaeolithic records of Circum-Baikal Asia began to decay at this stage (Konstantinov 1994; 2001; Aseev 2003; Philatov 2016). This tendency is clearly distinguished at the multi-layered sites of Transbaikalia, such as Studenoe-1 and Ust'-Menza-1. Here, large, steady in shape multi-fireplace structures represent the earliest of dwellings. They had a clear-cut layout and borders lined with stones. However, by around $1300014 \mathrm{C}$ bp they had already started degrading and turned into single-fireplace objects, and with each next horizon of the sites their construction elements were becoming more and more featureless. This tendency reaches its apogee in the horizons with pottery: residential structures here are distinguished solely by the concentration of finds near fireplaces. The general thinning of cultural deposits corresponds to these changes as well (Konstantinov 1994.150).

Secondly, some changes in the subsistence strategies also occurred at this phase. To begin with, fish bones and fishing tools appear here for the first time. Thus, fish bones are found in the Ust-Kyakhta-17, layers 2-6 (Tashak 2005), Oshurkovo, layer 3, Ust-Menza-1, layers 11-12, 9, Studenoe-1, layers 10-11 (Konstantinov 1994.148). Dace, roach, burbot, and pike were identified from bones recovered at the sites located along the Chikoi River. Bone fishhooks were found in the Ust-Kyakhta-3 site (Aseev 2006), Ust-Kyakhta17, layer 3 (Pavlenok 2015.147), Studenoe-1, layers 10-11 (Konstantinov 1994.80-81). Two bone harpoons were documented as well in layer 3 of Oshurkovo (Konstantinov 1994.149). Interestingly, in the horizons with pottery such clear evidence of fishing has not yet been found.

Besides, some changes in the design of the composite tools appeared at this phase. In addition to large one-edged shafts for microblades, their smaller-sized variety with a double-edge came into existence, as found at Ust-Menza-1, layer 12, Studenoe-1, layer 11, Ust-Kyakhta-17, layer 3 (Pavlenok 2015. 147). It is suggested that they were used for spears or darts (Konstantinov 1994.184). At the Studenoe-1, a double-edge shaft was found in the same layer with pottery (layer 9), but not in the upper horizons (Ibid. 81-84).

Thirdly, some changes are noted in microblade industries themselves (Antonova 2012; 2015; Moroz 2014b). Apart from the ongoing microblade miniaturization, the transition to raw materials of lower quality mentioned in the literature, there was also a change in microcore proportions, the improvement of microblade cutting, and the advent of points known as the Kyakhta type.

It is worth noting that all these features characterize only the sites located in the south of Transbaikalia. On these grounds, researchers combined them in the same cultural and chronological unit with an approximate age of 13-10 $000{ }^{14} \mathrm{C} \mathrm{bp} \mathrm{(Moroz} \mathrm{2014;} \mathrm{Pav-}$ lenok 2015). How these observations fit the more northern sites situated in the mouth of the Karenga River remains unclear. In addition, some time seems to pass between the starting of this culture and the coming of pottery, but it is difficult to determine how protracted this timelag was (Tab. 1; Konstantinov 1994; Kuzmin, Vetrov 2007; Razgil'deeva et al. 2013).

Moving people to a more mobile way of life is suggested to be a general tendency of the Neolithic transition in the Circum-Baikal area. This statement is in good correlation with some of the traits above, such as the miniaturization of microblades, simplification of house-building practices, and thinning of cultural deposits, while it does not fit well with others, such as the advent of pottery, birth of a fishing economy, and shift to a raw material of lower quality. This discrepancy stresses the complex nature of the processes happening in the given area in the course of the Neolithic transition.

The second phase started with the onset of the Holocene $\left(10300-7500{ }^{14} \mathrm{C} \mathrm{bp}\right)$. Two main events designate this period. On the one hand, there is evidence signalling the crash of cultural development in Transbaikalia, which was less pronounced in its

\begin{tabular}{|lccc|}
\hline & Ust'-Karenga-12 & Ust'-Menza-1 & Studenoe-1 \\
\hline Pre-ceramic & $12880 \pm 130-$ & $11820 \pm 120-$ & $12330 \pm 60-$ \\
layers & $12710 \pm 380$ & $10380 \pm 250$ & $10775 \pm 140$ \\
\hline Ceramic & $12180 \pm 60-$ & $11550 \pm 50$ & $10780 \pm 150-$ \\
layers & $10600 \pm 110$ & (food crust) & $10400 \pm 155$ \\
\hline
\end{tabular}

Tab. 1. Chronology of pre-ceramic and ceramic-bearing layers of the Transbaikalia Late Pleistocene sites. 
very northern part (Teten'kin 2010) (Fig. 3). Indeed, the ${ }^{14} \mathrm{C}$ dates of this age are almost absent in the current dataset (Konstantinov et al. 2016; see also Buvit et al. 2016). The few exceptions represent the dates derived from unclear stratigraphic, planigraphical and cultural contexts. On the other hand, multi-layered sites, like the Transbaikalia ones of the previous phase, came into existence in the Gisbaikal (Berdnikova et al. 2014; Losey, Nomokonova 2017). They are considered in the frame of the Mesolithic epoch, which means pottery completely disappeared in the Circum-Baikal region at the second phase.

The early Holocene assemblages of the Gisbaikal are typical for the classic Mesolithic epoch. The sites can be clustered into a few geographically isolated areas. Most of them concentrate on the north and south of Angara Region, and also on the west coast of Lake Baikal, by being tied to the edges of water holes. Their perfect stratigraphy allows tracing the incremental transformation of culture during this phase (Kol'tsov 1989; Bazaliyskiy 2012; Rogovskoy, Kuznetsov 2013; Bocharova et al. 2014; Berdnikov et al. 2014; Berdnikov 2016; Losey, Nomokonova 2017).

The cultural remains are mainly clustered around fireplaces, forming clear outlined spots. The dwelling-like structures are absent, but pits filled with ash and fish bones have been discovered. Hunting and fishing were the primary subsistence strategies. Faunal remains represent roe and red deer, and much more rarely elk and boar; however, the key tendency of the economic activity was the adoption of fishing. The increase in its significance is seen from the lowest to more and more upper horizons: the number of fish bones and fish tools accrue, simple fishhooks change to more effective composed tools, harpoons of a new design and weights also appear. Sturgeon, pike, burbot were the main objects of fishing. The role of seal was also growing in the course of this phase. The sites tied directly to Lake Baikal are broadly interpreted as seasonal fishers' camps.

The stone industries and tool assemblages also became more advanced, but most novelties arose only at the end of the phase. The progress in prismatic splitting and burin techniques was the principal tendency of that time, although bone and horn processing also flourished. The percentage of blade tools was high. Firstly the mid- and multi-facets burins and then their polyhedric varieties replaced the cor- ner ones. New techniques also emerged: grinding, drilling, bifacial processing. In addition, axes and adzes, including the ones with polished working edges, arrowheads, knives, as well as various decorative pendants appeared to supplement the assemblages.

The third phase (7500 ${ }^{14} \mathrm{C} \mathrm{bp}$ and onward) termed Neolithic in local schemes came with the advent of pottery and burials. And once again, some discrepancies between two opposite sides of Lake Baikal can be seen at this time. In Transbaikalia, this phase introduces only burial sites though with no pottery (Lbova, Zhambaltarova 2009). Dated habitation sites are still absent here up to approx. $5000{ }^{14} \mathrm{C} \mathrm{bp}$, and exceptions, once more, are few and obscure. (Aseev 2003; Hommel 2012; Konstantinov et al. 2016). In Gisbaikal, conversely, pottery and burials penetrated gradually into local assemblages starting yet in the Mesolithic phase (Weber 1995; Bazaliyskiy 2012; Berdnikov 2016; Berdnikov et al. 2017). Thus, single burials appeared at the end of the Mesolithic, while pottery-bearing sites coexisted with the aceramic ones for some time. For this reason, drawing a clear-cut border between the Mesolithic and Neolithic phases is not possible in this region. Besides, the subsistence strategies did not change significantly during Neolithic: deer, fish and seal were the staple foods at that time. The way of life also continued without pronounced changes.

The next noticeable shift in cultural development in the Circum-Baikal region occurred only much later, around $3000{ }^{14} \mathrm{C} \mathrm{bp}$. It was related to the arrival of pastoralist practices into this area and the rise the influence of nomadic culture.

\section{Central and North-Central China}

The archaeological records of China represent the third model related to the forming of agricultural communities. Since China was the only region in East Asia where the proper Neolithic formed, it has drawn the strongest attention of international scholars. As a consequence, many aspects of the Neolithic transition in China have been reappraised in recent years (Cohen 2003; 2011; 2013; 2014; 2017; BarYosef 2011a; Zhao 2011; Liu, Chen 2012; ShelachLavi 2015; Wagner, Tarasov 2014; Zhuang 2015; Liu X. et al. 2009; 2015; Liu L. 2015; Lu T. 2010; 2012; Wang et al. 2016; Lu H. 2017; Stevens, Fuller 2017; Crawford 2017; Chen, Yu 2017; He et al. 2017 ; etc.). And again, three phases can be seen in the course of food production forming. 


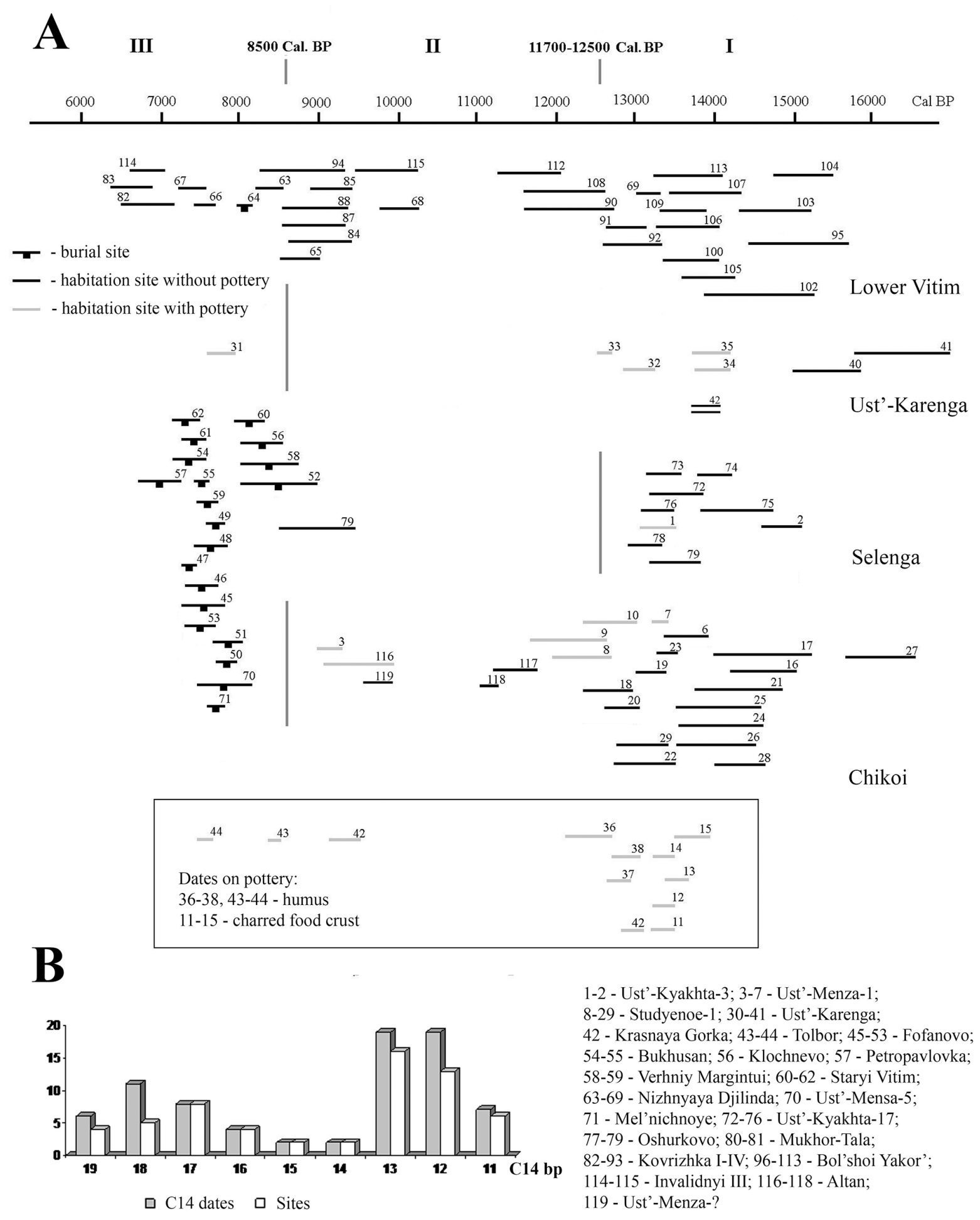

Fig. 3. Schematic representation of the Circum-Baikal radiocarbon date database referring to the Palaeolithic-Neolithic transition (A), and distribution of the number of dates under each millennium (B). Note the rise in the number of sites and dates during the 13'th to 11th millennia (B) and Early Holocene gap in the records (A).

The first phase $\left(17 / 11000-8200{ }^{14} \mathrm{C} \mathrm{bp}\right)$ is marked by the appearance of pottery and some other novelties, but this process proceeded with many differences in North and South China, and possibly asynchronously (Fig. 1).
In South China, a new cultural tradition was formed in the middle reaches of the Pearl River. People continued to dwell in caves and use pebble tools, like their Paleolithic predecessors, but pottery along with partly polished bone and shell tools, and oversized 
waste shells evidenced the advent of profound changes in their life. The chronology of this moment is unclear and still under discussion (Kuzmin 2013a; 2017; Cohen 2013; Cohen et al. 2017; Izuka 2018; Yanshina, Sobolev 2018). The recent ${ }^{14} \mathrm{C}$ dating refers it approx. to the Last Glacial Maximum (Boaretto et al. 2009; Wu et al. 2012), whereas more conservative assessments, based chiefly on cross-cultural comparisons, point out to the Pleistocene-Holocene boundary (MacNeish 1999; Zhao 1998; Wu et al. 2005; Chen 1999; Chi 1999). Later, but how much later it is unknown, isolated burials appeared there as well. Pottery has very distinctive appearances with no resemblance to any other known from that time outside of China (Yanshina 2017). So, it seems all the southern sites represent a homogeneous and well-clustered culture. Only a few sites are known outside it's areal, i.e. Xianrendong, Diaotonghuan, and Yuchanyan caves located in the juxtaposed Yangtze River basin. Interestingly, they show at the same time the most advanced assemblages: the majority of pottery, all finds of rice, and some progressive traits in stone tool manufacture were registered there.

In the North, emerging of pottery and partly polished stone axes indicates the arrival of the new phase. However, in contrast to the South, these novelties spread across a much wider area and turned to be embedded into at least two different cultural contexts.

The first and the earliest one is represented by the sites dated to the Bølling-Allerød warming and housed at the very north of Manchuria: Taoshan (Yang et al. 2017; Zou et al. 2018), Xiaonanshan (Heilongjiang Provincial Museum 1972; Barton 2009), Houtaomuga (Kunikita et al. 2017; Wang, Sebillaud 2019). Due to their location close to the Osipovka and Gromatukha cultures, pottery and stone tools peculiarities, they have to be considered as part of the Amur River cultures increasingly focusing on fishing (Kunikita et al. 2013; 2017). Thus, these sites might hardly characterize the forming of agriculture in China itself.

The second context is of greater interest from this point of view. It's related to the sites located along the eastern slope of the Loess Plateau, they are limited in number and seemingly reflect small disconnected groups of people. Grinding tools were found at all of the sites, being their only shared trait. In other respects, they were a rather heterogeneous and showed quite different assemblages with varying chronology and degree of 'neolithization'. From this perspective, three kinds of sites might be dis- tinguished there. The earliest one, dated to the Bølling-Allerød warming like on the North of Manchuria, is represented by the Yujiagou site with only one neolithic novelty, i.e. pottery. Then, at the very outset of the Holocene or a bit earlier, more 'neolithisized' kind of sites appeared in the Hebei province (Nanzhuangtou, Zhuannian, Donghulin, Yujiagou) (Liu, Chen 2012; Shelach-Lavi 2015) and in the upper stream of Huaihe River (Lingjing, Lijiagou) ( $L i$ et al. 2017). Finally, sites with assemblages similar to the early Neolithic Houli and Xinglongwa cultures arose in Shandong Province (Zhangmatun, Bianbiandong) (Wu et al. 2014; Sun et al. 2014) and in the south of Manchuria respectively (Xiaohexi culture sites) (Wagner 2006), being dated, however, a little before them.

Their stone assemblages keep the Upper Palaeolithic microblade industries, though at some this was already not the case. The settlement structures differing from the Palaeolithic are registered, but they have no repeated traits. It might be pits filled with ash and organics; fireplaces filled with stones or animal bones, or coal and burnt clay concentrations. Pottery at some instances looks like the ceramics of the Amur River (Yujiagou, Nanzhuangtou), but in others it shares some traits with ceramics of the Jomon culture (Lijiagou) or is featureless and therefore remains without any analogies (Lingjing, Zhuannian, Donghulin).

In general, as opposed to the South, the North sites appear to reflect a rather feeble and dissipated process. At the same time, it cannot exclude that this impression is partly the result of the information scarcity.

Changes in the subsistence strategies at this phase are the main focus of scholars, since they are looking for the roots of Chinese agriculture. In the southern part of China, these changes were nonetheless the most pronounced in the field of hunter-gatherer activities. Here, the gathering of freshwater molluscs developed and gained impetus. With regard to gathering plants, rice remains were discovered at some of the sites housed along the Yangtze River, but only very few in number (Zhao 1998; Lu T. 2009; 2010; 2012). In the northern part of China, conversely, plant gathering started to thrive, as can be seen from increasing number of grinding tools with starch remains of cereal, nuts, acorns and root crops, although hunting seemed to be the main activity (Liu, Chen 2012; Yang et al. 2012; 2014; 2015; Liu 2015; Wang et al. 2016). It should be stressed here in reference 
to the plants found at this phase in both parts of China that their position along the path between wild and domesticated forms remains an open question, but in any case, the practice of plant gathering only started to form as a regular part of the subsistence during this phase.

The second phase (8200-6000 14 C bp) started with the 'sudden' appearance of early agricultural communities, first in the low and middle parts of the Yangtze River, and then in more and more northern areas up to the southern part of Manchuria. Despite the fact that their examination has been ongoing for several decades, in recent years there have been major changes in the assessments in this field. This is due to the fact that the economies of such communities have turned out to correspond to only incipient or low-level agriculture (Smith 2001), as indicated by a whole range of data.

Firstly, recent studies revealed that the millet and rice domestication process was only at its very starting point at this time. The earliest remains of these plants found at the sites show either evi-dence that they were at the very beginning of the transformation process, or have questionable status (Fuller et al. 2008a; Jones, Liu 2009; Zhao 2011; Barnes 2015; Stevens, Fuller 2017; Crawford 2017).

Secondly, paleobotanical assemblages point to the fact that millet and rice constituted only a minor part of the people's diets, no more than $20 \%$ based on various evidence, whereas nuts, acorns and root crops dominated. Similar results follow from the isotopic studies of North China, showing no more than 20$25 \%$ of the diet was from millet ( $L i$, Chen 2012; Chen, $Y u$ 2017).

Thirdly, tool assemblages also match well with new assessments, though north and south sites differ in this regard (Liu, Chen 2012; Chen, Yu 2017). In North China, apart from the grinding equipment, specialized polished sickle-like knives were also used, and their proportion increased over the time. Such tools has not been registered at all in the lower part of the Yangtze River, while ordinary flint flakes which could be used as sickles are known in its middle stream. In contrast, grinding tools were absent in the middle part of the Yangtze River, but present in its lower course. It is interesting that they markedly differed from the ones being in circulation in North China. Moreover, in both rivers basins there were no special tools for soil preparation (Fuller et al. 2008; Makibayashi 2014).
Fourthly, palynological data also indicate the lowproductive nature of farming, albeit indirectly. According to the results of recent studies, at this stage there was no reduction in the area occupied by forests, which is usually observed under intensive agricultural management (Ren 2007). The content of coal and weeds remains relatively low as well.

It should be noted it is hard if not impossible to trace any dynamics in the cultural development during this phase. This is especially true when it comes to the process of agriculture evolving, as well as settlements, dwellings and other indicators of lifestyle. They remained almost unchanged throughout the phase up to the stage of the Yangshuo culture, while tool assemblages developed a bit more dynamically (Liu, Chen 2012; Chen, Yu 2017).

The third phase (6000-5500 ${ }^{14} \mathrm{C} \mathrm{bp}$ and onward) comes with the appearance of much more developed cultures like the Yangshuo, Hemudu, and Daxi. Absolutely all indicators mentioned above changed drastically at this stage (see reviews in Liu, Chen 2012; Shelach-Lavi 2015), mirroring as well the establishment of much more intensive agriculture (Barton 2009; Stevens, Fuller 2017). Concurrently, there was a sharp increase in the population which is assessed based on the rise in total amount of archaeological sites, their size and the areas occupied by farmers ( $L i$ et al. 2009; $W u$ et al. 2014; Hosner et al. 2016; $L u$ et al. 2018). Many sources also indicate the rising complication of social life and ritual practices (Liu 2005; Shelach-Lavi 2015). Moreover at this phase, although with some delay in the south, we see the spreading of agriculture into new areas due to the growth of its influence and the opportunities to engage in it (Zhang, Hung 2010; 2013; Fuller et al. 2007.325-326).

Such tripartition of the Neolithic transition is not something new, and the specific nature of its three consequent phases are obvious to all specialists. The major problem in this field concerns searching for the roots of Chinese agriculture. The first agricultural communities show only the incipient level of agriculture, but other constituents of the Neolithic package they possessed were already very sophisticated, although their origins still remain unclear.

Thus, the early agriculturalists of China lived in village-like settlements or in proper villages. The biggest of them included tens of dwellings, burials and hundreds of household pits; they were often organized according to a well-defined layout, had pot- 
tery kilns, and were enclosed by ditches. Their pottery was of high quality and differed much from the previous types, except that which originated in South China. Its shapes were surprisingly diversified, as they were already well adapted to special functions; their set and painted patterns was typical for farmers over all of Eurasia, but diverged significantly from the vessels of the surrounding hunter-gatherers. Advanced burial practices also appeared at this phase along with other kinds of ritual activity, while less pronounced. The cemeteries were located as a rule near the habitation sites and featured steady ceremonial traits with regard to the shape and disposition of graves, set of grave goods, body position of dead and their orientation, post-mortem manipulations, sacrificial offerings, etc.

\section{Distinguishing the Neolithic transition in East and West Asia}

For a start, let us look at the general timeline of the Neolithic transition in East Asia. Summing up the above data, we can get the scheme where two stages are clearly distinguished (Fig. 4). The first concerns the forming of more sophisticated and equipped cultures of hunter-gatherer-fishers. It seems this process started earlier and was more fast-paced and more innovative in the Japanese archipelago. Here, we can trace two successive phases of the transition with different suites of the novelties: the first in the north of Honshu and the second in the south of Kyushu (Fig. 4). The second stage concerned the transition to food production, and this process was explicitly concentrated in central and north-central China. Between these two stages, we can also see a cultural, spatial and temporal gap in records splitting up the Neolithic transition into two seemingly isolated episodes. This is why it is hard to conceive it as an incremental and coherent process, as we can observe in West Asia.

Next, we can see that in each of the East Asia regions considered above, the transition to the Neolithic was run according to its own distinctive scenario. In each of the regions we have an individual set of novelties which differs in each case in a special manner from the classical package formed in West Asia. However, if we take East Asia as a whole and consider what specific innovations, where and in what sequence arose during the Neolithic transition, we will see a process that differs little from that is known in the Near East. It will become obvious that the Neolithic transition in both regions had the same vector and went through the same stages: (1) the broad spectrum economy (Binford 1968; Flannery 1969; Zeder 2012); (2) low-level food production (Smith 2001); (3) the establish-ment of fully developed agriculture, i.e. based primarily on domesticated species (Asouti, Fuller 2013; Stevens, Fuller 2017; Freeman et al. 2015).

The terms used above are based mainly on the West Asia data. Nonetheless, in East Asia researchers also use them or their equivalents widely, though predominately to interpret the Chinese materials (see, for example, the broad spectrum revolution: $\mathrm{Habu}$ 2004; Lu 2006; Prendergast et al. 2009; Elston et al. 2011; Shelach-Lavi 2015.52-66; Morgan et al. 2017.18; low level production: Crawford 2006; Barton 2009; Bettinger et al. 2010; Liu, Chen 2012.125,

168; Shelach-Lavi 2015. 149; Pan et al. 2017.366367). Herewith, if the concept of low-level production seems in good correspondence with East Asia records, then this might not be so obvious with respect to the concept of a broad-spectrum revolution. This is particularly the case with regard to Japan, Far East Russia, and Transbaikalia, and special research is required to illuminate this question. In the almost complete absence of zooarchaeological and paleobotanical data

Fig. 4. General timeline of the Neolithic transition in East Asia. 
reflecting the Terminal Pleistocene in these regions, chiefly technological changes can be used there as the marks of resource spectrum broadening or resource intensification.

Further, on the basis of these observations we can synchronize the events related to the Neolithic transition in both East and West Asia (Tab. 2).

The synchronization shows clearly that the Neolithic transition started in East Asia approximately at the same time as in West Asia, i.e. on the eve of the Bølling-Allerød warming, but ended much later. At the dawn of the Holocene, this lag became more noticeable. Despite the early appearance of pottery together with other innovations mentioned above, the domestication process began and ended in East Asia later, and it concerns as well a sedentary way of life, intensive agriculture, and its transmission into new areas occupied by hunter-gatherers.

What were the reasons for this lag? It appears different economic strategies underlay the Neolithic transition in West and East Asia during its first steps. The Natufian culture had a complex subsistence practice, and from the very beginning it had been distinctly specializing in harvesting plant resources (Weiss et al. 2004), but in East Asia this was not the case. Here, in the first instance, a more advanced culture of hunter-gatherer-fishers was established, and only after this did cultures somewhat similar in their economy to the Natufian one appear on the south of Kyushu, but with no time to gain strength since their development was soon interrupted by the Younger Dryas cooling.

This climatic event equally affected the plant gathering in both West and East Asia (Bar-Yosef 2011b). In the former, it led to the decline of the Natufian culture, but at the same time to the dissemination of its main achievements. On these grounds, the PPN cultures arose soon after. In East Asia, plant gathering, which had already starting later, was interrupted, and for a much more extended time, including into

\begin{tabular}{|lcccc|}
\hline & West Asia & Cal bp & East Asia & Cal bp \\
\hline $\begin{array}{l}\text { Broad spectrum } \\
\text { economy }\end{array}$ & Natufian & $15000-11500$ & Proto-Jomon & $16000-11500$ \\
\hline $\begin{array}{l}\text { Low level } \\
\text { production }\end{array}$ & PPN & $11500-8200$ & Peiligang & $8200-6800$ \\
\hline $\begin{array}{l}\text { Intensive } \\
\text { agriculture }\end{array}$ & PN & $>8200$ & Yangshuo & $>6800$ \\
\hline
\end{tabular}

Tab. 2. Rough synchronization of the main steps of Neolithic transition in East and West Asia. the Early Holocene. It seems also that on the Japanese archipelago, given its geographical setting, the successful evolution of plant resource specialization into intensive agriculture was a priori impossible or at least much more difficult (Bleed, Matsui 2010). Perhaps due to these circumstances, in East Asia plant resources fell into the focus of subsistence practices only much later, and in a more relevant place, namely China.

The core-area displacement from the Japanese archipelago and Amur river region to China during the process of Neolithization, most likely, also influenced its pace, and this concerns not only the development of plant gathering itself. In Western Asia we can also see such a displacement, but it was accompanied by a continuity in cultural development, whereas in East Asia it coincided with a deep spatial, temporal and moreover cultural gap.

To date, no clearly expressed cultural links between China and the Japanese archipelago (or Amur River region) are yet visible in the course of Neolithization. The data on the two first Holocene millennia are not within the main research focus, and also remain too scarce. We do not know if there was a relay-like transmission of cultural baggage, or if the early agriculturalists started moving to food production based only on the achievements of their local ancestors. The latter, however, were rather moderate in comparison to those framed in the southern part of the Japanese archipelago. Nonetheless, early agricultural communities appeared to be well-formed in China, and due to the gap mentioned it is still difficult to find the origins of their high culture. This is in sharp contrast to West Asia, where we see an incremental moving to more and more sophisticated cultures.

One more feature becomes obvious when comparing the western and eastern trajectories of the Neolithic transition, and this concerns the so-called Subneolithic cultures. According to most definitions, they possess all, almost all, or some of the Neolithic novelties, except agriculture, though we do not understand the whole spectrum of their varieties. However, it appears our comparative analysis permits us to solidly differentiate them into two main kinds: Meso-Neolithic and Subneolithic. It seems they differ chiefly by the extent of sedentarization as indicated by 
the presence/absence of village-like settlements. From this, we might see the notional sequence 'Mesolithic- Subneolithic-Neolithic' where pottery distinguishes the Mesolithic and Subneolithic, but agriculture separates the Neolithic and Subneolithic. Besides, it sounds like this partitioning is relevant not only for East Asia, but also for most of Eurasia.

In the West, both Subneolithic and Meso-Neolithic cultures become ubiquitous only after intensive agriculture develops in the Near East. Moreover, it is well known that their advent was caused by the influence of agriculturalists. Conversely, in the East, Subneolithic and Meso-Neolithic cultures arose across the whole area more or less simultaneously with the first low-level agriculture communities. This means that their forming started even earlier. In East Asia, the pioneering hunter-gatherer-fisher cultures of the first stage of the Neolithic transition engendered the whole range of Neolithic innovations, and possibly imparted them to the early agriculturalists, but not the reverse. This fact makes the Neolithic transition in East Asia unique, and not only due to the earlier appearance of pottery. It emerged together with other novelties typical for the Neolithic, Meso-Neolithic and Subneolithic cultures of all Eurasia.

\section{Conclusions}

Taking stock of all the above data and considerations, we can reach the following conclusions.

Firstly, there were three dissimilar models of the Neolithic transition in East Asia: the Meso-Neolithic in the Circum-Baikal region, the Subneolithic in the Sea of Japan area, and the Neolithic in China. They vary widely, but at the same time, have an important commonality concerning the suite of Neolithic novelties. In each region we observe their individual set, but it always remains within the frame of the classic Neolithic package. Thus, in light of this pattern, the main question is why the transition to the Neolithic was so similar in different regions.

Secondly, two stages and two centres might be clearly recognized during the Neolithic transition in East Asia. The early stage concerned the so-called broad spectrum revolution leading to the origin of more sophisticated and newly equipped hunter-gathererfisher cultures. This process was rather diffuse, but seems to have started earlier and was more fastpaced and more innovative in the Japanese archipelago. At the second stage, the transition to food production started in central and north-central China.
There we observe further progressive development toward the Neolithic, and China clearly becomes the centre of the Neolithization process. Between the stages, there is a clear cultural, spatial and temporal gap splitting up the Neolithization process into two isolated episodes. However, a more comprehensive analysis of the records bearing on the first millennia of Holocene is needed to assess whether this gap is artificial or reflects an objective picture

Thirdly, the early emergence of pottery was not the only feature of the East Asia Neolithic transition. Most crucially, it appeared together with other novelties typical for the classic Neolithic package. Moreover, they were all embedded in a process leading to the forming of a new type of hunter-gatherer-fisher culture known in the literature as the Subneolithic. It seems the early dates of pottery acted as a red herring in Neolithic studies, hindering the understanding of this pattern. In addition, this process occurred at the end of the first stage mentioned above, i.e. prior to early agriculture. Further, for a long time afterward the relationships between the first agriculturalists and surrounding Subneolithic communities were not like those between the centre and periphery, and this shift happened only after several thousands of years when intensive agriculture had been established.

$$
\text { ACKNOWLEDGEMENTS }
$$

The author gratefully acknowledges various colleagues and friends for their assistance in this study. First of all, I would like to thank I. Y. Shewkomud, Onuki Shizuo, V. M. Vetrov, Y. V. Kuzmin, A. A. Tsydenova, O. L. Moreva, M. V. Konstantinov, I. Y. Razgildeeva, A. V. Garkovik, A. P. Derevyanko, S. P. Nesterov, A. V. Tabarev, A. A. Vasilevsky, S. V. Grishchenko, O. A. Shubina, Masahiro Fukuda, Isao Usuki, S. Shinya, P. Hommel, and many others for helpful discussions, valuable suggestions and making the foreign papers available to me. My thanks go also to M. Budja and A. Vybornov for an invitation to contribute to this volume. Financial assistance was provided by the Russian Academy of Sciences. 


\section{References}

Andreeva Z. (ed.) 1991. Neolit yuga Dal'nego Vostoka: Drevnee poselenie v pezhchere Chertovye Vorota. Nauka. Moscow. (in Russian)

Antonova Y. 2012. Selenginskaya industriya v finale paleolita Zapadnogo Zabaykalia: k voprosu o mezhkulturnom vzaimodeystvii. In D. Tumen, M. Erdene, and E. Mijiddorj (eds.), Drevniye kultury Mongolii i Baykalskoy Sibiri. Materialy III Mezhdunarodnoynauchnoy konferentsii (Ulan-Bator, 05-09 sentyabrya 2012). National University of Mongolia. Ulan-Bator: 1-7. (in Russian)

2015. Kamennaya industria mestonahozhdeniya Dabhur (Zapadnoe Zabaikalie): Voprosy kulturno-chronologicheskoi identifikatsii. In B. V. Bazarov (ed.), Aktual'nye voprosy arheologii I etnologii Tsentral'noy Azii. Materialy mezhdunarodnoy nauchnoi konferentsii (UlanUde, 7-8 aprelya 2015). Ottisk. Irkutsk: 31-38. (in Russian)

Aseev I. 2003. Yugo-Vostochnaya Sibir' v epohu kamnya I metalla. Institute of Archaeology and Ethnography. Siberian Branch of Russian Academy of Sciences. Novosibirsk. (in Russian)

Asouti E., Fuller D. 2013. A Contextual Approach to the Emergence of Agriculture in Southwest Asia: Reconstructing Early Neolithic Plant-Food Production. Current Anthropology 54(3): 299-345. https://doi.org/10.1086/670679

Barnett W., Hoppes J. 1995. The shape of early pottery studies. In W. Barnett, J. Hoppes (eds.), The emergence of pottery: Technology and innovation in Ancient Societies. Smithsonian Institution Press, Washington and London: $1-7$.

Barton L. 2009. Early Food Production in China's Western Loess Plateau. Unpublished Ph.D dissertation. Department of Anthropology. University of California. Davis.

Bar-Yosef 0. 2011 a. Early origin of agriculture and World Heritage: the role of Asia. World Heritage Paper 29: 172189.

2011b. Climatic fluctuations and Early Farming in West and East Asia. Current Anthropology 52(4): S175- S193. https://www.journals.uchicago.edu/doi/abs/10.1086/ 659784

Bae K. 2010. Origin and patterns of the Upper Paleolithic industries in the Korean Peninsula and movement of modern humans in East Asia. In Quaternary International 211: 103-112. https://doi.org/10.1016/j.quaint.2009.06.011

2017. Paleolithic Archaeology in Korea. In J. Habu, P. Lape, and J. Olsen (eds.), Handbook of East and South- east Asian Archaeology. Springer Science+Business Media, LLC. New-York: 219-239.

https://doi.org/10.1007/978-1-4939-6521-2_1

Barnes G. 2015. Archaeology of East Asia: The Rise of Civilization in China, Korea and Japan. Oxbow Books. Oxford.

Batarshev S. 2009. Rudninskaya archeologicheskaya kul'tura $v$ Primorye. Reya. Vladivostok. (in Russian)

Bazaliyskiy V. 2012. Pogrebalnye kompleksy epohi pozdnego mesolita - neolita Baikal'skoy Sibiri: traditsii pogrebeniy, absolyutnyi vosract. Reports of the Laboratoty of ancient Technologies 9: 43-101. (in Russian)

Berdnikova N. 2012. Zaklyuchitel'naya stadiya pozdnego paleolita yuga Baikal'skoi Sibiri. Geoarheologicheskiye cyuzhety. In Pervobytnye drevnosti Evrasii: $k$ 60-letiyu Sorokina A. N. Institute of Archaeology. Russian Academy of Sciences. Moscow: 103-122. (in Russian)

Berdnikova H., Berdnikov I., Vorob'eva G., Rogovskoy E., Klement'ev A., Ulanov I., Lokhov D., Dudaryek S., Novosel'tseva V., and Sokolova N. 2014. Geoarheologicheskie komplexy rannego golotsena na yuge Sredney Sibiri: Otsenka dannyh I perspectivy issledovaniy. Izvestiya Irkutskogo Gosudarstvennogo universiteta. Seriya Geoarheologiya. Etnologiya. Antropologiya 9: 46-76. (in Russian)

Berdnikov I. 2016. Aktual'nye problemy neolitovedeniya yuga Sredney Sibiri: istichnikovaya baza I geoarcheologicheskiy context. Izvestiya Irkutskogo Gosudarstvennogo universiteta. Seriya Geoarheologiya. Etnologiya. Antropologiya 18: 3-39. (in Russian)

Berdnikov I., Ulanov I., and Sokolova N. 2017. Neoliticheskoye goncharstvo Baikalo-Eniseyskoy Sibiry: tekhnologicheskie traditsii v teritorial'no-hronologicheskom kontekste. Stratum Plus 2: 275-300. (in Russian)

Bettinger R., Barton L., and Morgan C. 2010. The origins of food production in North China: A different kind of agricultural revolution. Evolutionary Anthropology 19: 9-21. https://doi.org/10.1002/evan.20236

Binford L. 1968. Post Pleistocene adaptations. In S. R. Binford, L. R. Binford (eds.), New perspectives in archeology. Aldine Publishing Company. Chicago: 23-49.

Björk K. 1998. A comparative outline of the Early Neolithic cultures in China and the Near East. Documenta Praehistorica 25: 37-52.

Bleed P., Matsui A. 2010. Why didn't agriculture develop in Japan? A consideration of Jomon ecological style, niche 
construction, and the origins of domestication. Journal of Archaeological Method and Theory 1: 356-370.

https://doi.org/10.1007/s10816-010-9094-8

Boaretto E. and 12 co-authors. 2009. Radiocarbon dating of charcoal and bone collagen associated with early pottery at Yuchanyan Cave, Hunan Province, China. Proceedings of the National Academy of Sciences of the USA 106(25): 9595-9600.

https://doi.org/10.1073/pnas.0900 539106

Bocharova E., Timozhchenko A., and Savel'ev N. 2014. Perehod ot mezolita $\mathrm{k}$ neolitu: chronologicheskie granitsy $\mathrm{i}$ stepen' kul'turnoy preemstvennosti (Po materialam mnogosloinogo mestonahozhdeniya Kazachka 1). Novosibirsk State University Bulletin. Series: History and Philology 13(5):125-134. (in Russian)

Budja M. 2006. The transition to farming and the ceramic trajectories in Western Eurasia from ceramic figurines to vessels. Documenta Praehistorica 33: 183-201. https://doi.org/10.4312/dp.33.17

2016. Ceramics among Eurasian hunter-gatherers: 32000 years of ceramic technology use and the perception of containment. Documenta Praehistorica 43: 61-86. https://doi.org/10.4312/dp.43.2

Buvit I., Izuho M., Terry K., Konstantinov M., and Konstantinov A. 2016. Radiocarbon dates, micro-blades and Late Pleistocene human migrations in the Transbaikal, Russia and the Paleo-Sakhalin-Hokkaido-Kuril Peninsula. Quaternary International 425: 100-119.

https://doi.org/10.1016/j.quaint.2016.02.050

Chen S., Yu P. 2017. Intensified foraging and the roots of farming in China. Journal of Anthropological Research 73(3): 381-412. https://doi.org/10.1086/692660

Chen X. 1999. On the earliest evidence for rice cultivation in China. Bulletin of the Indo-Pacific Prehistory Association 18: 81-93.

http://dx.doi.org/10.7152/bippa.v18i0.11701

Chi Z. 1999. The excavation at Xianrendong and Diaotonghuan, Jiangxi. Bulletin of the Indo-Pacific Prehistory Association 18: 97-100.

http://dx.doi.org/10.7152/bippa.v18i0.11703

Close A. 1995. Few and Far Between. In W. Barnett, J. Hoopes (eds.), The emergence of pottery: Technology and innovation in Ancient Societies. Smithsonian Institution Press. Washington and London: 23-37.

Cohen D. 2003. Microblades, pottery, and the nature and chronology of the Paleolithic-Neolithic transition in China. The Review of Archaeology 24(2): 21-36.
2011. The Beginnings of agriculture in China: A Multiregional View. Current Anthropology 52 (4): 273-293. http://dx.doi.org/10.1086/659965

2013. The advent and spread of early pottery in East Asia: new dates and new considerations for the world's Earliest ceramic vessels. Journal of Austronesian Studies 4(2): 55-91.

2014. The Neolithic of Southern China. In C. Renfrew, P. Bahn (eds.), The Cambridge World Prehistory. Cambridge University Press. Cambridge: 765-781.

https://doi.org/10.1017/CHO9781139017831.053

Cohen D., Bar-Yosef O., Wu X., Patania I., and Goldberg P. 2017. The emergence of pottery in China: Recent dating of two early pottery cave sites in South China. Quaternary International 441: 36-49.

https://doi.org/10.1016/j.quaint.2016.08.024

Craig 0. and 13 co-authors. 2013. Earliest evidence for the use of pottery. Nature 496: 351-354.

https://doi.org/10.1038/nature12109

Crawford G. 2006. East Asian Plant Domestication. In M. Stark (ed.), Archaeology of Asia. Blackwell Publishing. Oxford: 77-95.

https://doi.org/10.1002/9780470774670.CH5

2017. Plant Domestication in East Asia. In J. Habu, P. V. Lape, and J. W. Olsen (eds.), Handbook of East and Southeast Asian Archaeology. Springer Science+Business Media LLC. New-York: 421-430.

https://doi.org/10.1007/978-1-4939-6521-2_26

Derevyanko A. P., Medvedev V. E. 1995. The Amur river basin as one of the earliest centers of ceramics in the Far East. In H. Kajiwara (ed.), The Origin of Ceramics in the East Asia and the Far East. Abstracts of International Symposium, Sendai, September 29-October 5, 1995. Tokhoku University. Sendai: 13-25.

2006. Neolithic of the Nizhnee Priamurye. In S. Nelson, A. Derevyanko, Y. Kuzmin, and R. Bland (eds.), Archaeology of the Russia Far East: Essays in stone age prehistory. British Archaeological Reports IS 1540. Archaeopress. Oxford: 123-149. (in Russian)

Derevyanko A., Tabarev A. 2006. Paleolithic of the Primorye (Maritime) province. In S. Nelson, A. Derevyanko, Y. Kuzmin, and R. Bland (eds.), Archaeology of the Russia Far East: Essays in stone age prehistory. British Archaeological Reports IS 1540. Archaeopress. Oxford: 41-54.

Derevianko A., Derevianko E., Nesterov S., Tabarev A., Uchida K., Kunikita D., Morisaki K., and Matsuzaki H. 2017. New data on the chronology of the initial neolithic 
Gromatukha culture, western Amur region. Archaeology, Ethnology \& Anthropology of Eurasia 45(4): 3-12.

Dyakov V. 1992. Mnogosloynoe poselenie Rudnaya Pristan' $i$ periodizatsia neoliticheskikh kultur Primorya. Dal'nauka. Vladivostok. (in Russian)

Eerkens J., Lipo C. 2014. A tale of two technologies: Prehistoric diffusion of pottery innovations among huntergatherers. Journal of Anthropological Archaeology 35: 23-31. https://doi.org/10.1016/j.jaa.2014.04.006

Finlayson B. 2013. Imposing the Neolithic on the past. Levant 45(2): 133-148.

https://doi.org/10.1179/0075891413Z.00000000021

Freeman J., Peeples M., and Anderies J. 2015. Toward a theory of non-linear transitions from foraging to farming. Journal of Anthropological Archaeology 40: 109-122. https://doi.org/10.1016/j.jaa.2015.07.001

Fukuda M., Shewkomud I. Y., Morisaki K., and Kumaki T. (eds.) 2014. An archaeological study on prehistoric cultural interaction in the Northern Circum Japan sea area: Yamikhta site excavation report. Tokoro Research Laboratory of the University of Tokyo. Tokyo. (In Japanese, Russian, English)

Fuller D., Qin L., and Harvey E. 2008. A critical assessment of early agriculture in East Asia, with emphasis on Lower Yangzte rice domestication. Pragdhara 18: 17-52.

Fuller D., Willcox G., and Allaby R. 2011. Cultivation and domestication had multiple origins: arguments against the core area hypothesis for the origin of agriculture in the Near East. World Archaeology 43(4): 628-652.

https://doi.org/10.1080/00438243.2011.624747

Fuller D., Stevense S. 2017. Open for competition: domesticates, parasitic domesticoids and the agricultural niche. Archaeology International 20: 110-121.

http://doi.org/10.5334/ai.359

Garkovik A. 1996. Nekotorye itogi issledovaniya stoyanki Ustinovka-3 v Primorye. In Pozdniy paleolit - ranniy neolit Vostochnoy Asii I Severnoy Ameriki. Institute of History, Archaeology and Ethnography of the Peoples of the Far-East. Far-Eastern Branch of Russian Academy of Sciences. Vladivostok: 58-65. (in Russian)

Gibbs K. 2015. Pottery Invention and Innovation in East Asia and the Near East. Cambridge Archaeological Journal 25(1): 339-351.

https://doi.org/10.1017/S0959774314001139

Gibbs K., Jordan P. 2013. Bridging the boreal forest Siberian archaeology and the emergence of pottery among prehistoric Hunter-gatherers of Northern Eurasia. Sibirica 12(1): 1-38. https://doi.org/10.3167/sib.2013.120101

2016. A comparative perspective on the 'western' and 'eastern' Neolithics of Eurasia: Ceramics; agriculture and sedentism. Quaternary International 419: 17-35. https://doi.org/10.1016/j.quaint.2016.01.069

Grishchenko S. 2011. Ranniy Neolit ostrova Sakhalin. Sakhalin State University. Yuzhno-Sakhalinsk. (in Russian)

Habu J. 2004. Ancient Jomon of Japan. Cambridge University Press. Cambridge.

He K., Lu H., Zhang J., Wang C., and Huan X. 2017. Prehistoric evolution of the dualistic structure mixed rice and millet farming in China. The Holocene 27(12): 18851898. https://doi.org/10.1177/0959683617708455

Heilongjiang Provincial Museum (eds.) 1972. The excavation of the Xiaonanshan site in Raohe county, Heilongjiang. Kao Gu Xue Bao 2: 32-34. (in Chinese)

Hommel P. 2012. The emergence of ceramics among Hunter-gatherers in Nothern Eurasia. The Neolithic ceramics of the Upper Vitim Basin, Nothern Transbaikal, Siberia. Unpublished PhD Thesis. University of Sheffield. Sheffield.

Hommel P., Schwenninger J., Ineshin E., and Vetrov V. M. 2017. Testing times: an evaluation of the radiocarbon chronology for early ceramic vessel production at Ust'-Karenga. Reports of the Laboratory of Ancient Technologies 13(1): 31-46.

https://doi.org/10.21285/2415-8739-2017-1-31-46

Hosner D., Wagner M., Tarasov P., Chen X., and Leipe C. 2016. Spatiotemporal distribution patterns of archaeological sites in China during the Neolithic and Bronze Age: An overview. The Holocene 26(10): 1576-1593. https://doi.org/10.1177/0959683616641743

Huyseco E., Rasse M., Lespez L., Neumann K., Fahmz A., Ballouche A., Oyainne S., Maggetti M., Tribolo C., and Soriano S. 2009. The emergence of pottery in Africa during the tenth millennium cal BC: new evidence from Ounjougou (Mali). Antiquity 83: 905-917.

https://doi.org/10.1017/S0003598X00099245

Imamura K. 1996. Prehistoric Japan: New Perspectives on Insular East Asia. University College London Press. London.

Izuka F. 2018. The timing and behavioral context of the Late-Pleistocene adoption of ceramics in Greater East and Northeast Asia and the first people (without pottery) in the Americas. PaleoAmerica 4(4): 267-324. https://doi.org/10.1080/20555563.2018.1563406 
Izuka F., Izuho M. 2017. Late Upper Paleolithic - Initial Jomon transition, southern Kyushu, Japan: Regional scale to macro processes a close look. Quaternary International 441: 102-112.

https://doi.org/10.1016/j.quaint.2016.12.040

Ikawa-Smith F. 2017. Paleolithic Archaeology in Japan. In J. Habu, P. Lape, and J. Olsen (eds.), Handbook of East and Southeast Asian Archaeology. Springer Science+Business Media, LLC. New-York: 194-217.

https://doi.org/10.1007/978-1-4939-6521-2_16

Jesse F. 2003. Early ceramics in the Sahara and Nile Valley. In L. Krzyzanik, K. Kroeper, and K. Kobuseiwicy (eds.), Cultural markers in the later prehistory of Northeastern Africa and recent research. Studies in Africa Archaeology 8. Posnan Archaeological Museum. Poznan: 35-50.

Jones M., Liu X. 2009. Origins of Agriculture in East Asia. Science 324(5928): 730-731.

https://doi.org/10.1126/science.1172082

Jordan P., Zvelebil M. 2009. Ex Oriente Lux: The prehistory of Hunter-Gatherer Ceramic Dispersals. In P. Jordan, M. Zvelebil (eds.), Ceramics before farming: The dispersal of Pottery Among Prehistoric Eurasian Hunter-Gatherers. Left Coast Press. Walnut Creek: 33-90. https://doi.org/10.4324/9781315432373

Kajiwara H., Kononenko A. 1999. The origin of early pottery in Northeast Asia in the context of environmental change. Proceedings of the Society for California Archaeology 12: 64-79.

Kanner S. 2009. Long-term innovation: Appearance and spread of pottery in the Japanese Archipelago. In P. Jordan, M. Zvelebil (eds.), Ceramics before farming: The dispersal of Pottery Among Prehistoric Eurasian Hunter-Gatherers. Left Coast Press. Walnut Creek: 93-114. https://doi.org/10.4324/9781315432373

Kaner S., Taniguchi Y. 2017. The development of pottery and associated technological developments in Japan, Korea, and the Russian Far East. In J. Habu, P. Lape, and J. Olsen (eds.), Handbook of East and Southeast Asian Archaeology. Springer Science+Business Media, LLC. NewYork: 321-345.

https://doi.org/10.1007/978-1-4939-6521-2_22

Kanomata Y. 2010. The relationship between human and environment from the end of Pleistocene to the beginning of Holocene in Japan. In Technological evolution through the end of the Paleolithic: A comparative perspective from France. The graduate GP International Simposium. Tohoku University. Sendai: 100-108.

Keally C., Taniguchi Y., and Kuzmin Y. 2003. Understanding the beginning of pottery technology in Japan and neighboring East Asia. The Review of Archaeology 24(2): $3-15$.

Keally C. 1991. Environment and the distribution of sites in the Japanese Palaeolithic: Environmental zones and cultural areas. Bulletin of the Indo-Pacific Prehistory Association 10: 23-39.

Kenrick K. 1995. Jomon of Japan: The World's oldest pottery. Kegan Paul International. London. New York.

Kobayashi T. 2004. Jomon reflections: Forager life and culture in the prehistoric Japanese Archipelago. Oxbow books. Oxford.

Kol'tsov L. (ed.). 1989. Mezolit SSSR. Nauka. Moscow. (in Russian)

Konstantinov A. 2001. Drevnie zhilizhcha Zabaikalia (paleolit, mezolit). Nauka. Novosibirsk. (in Russian)

Konstantinov M. 1994. Kamennyi vek vostochnogo regiona Baikalskoi Ayii. Institute for Mongolian, Buddhist and Tibetan Studies of the Siberian Branch of Russian Academy of Sciences and Transbaikal State University. Ulan-Ude-Chita. (in Russian)

2009. Radiouglerodnaya anomaliya v datirovanii pozdnego mezolita i neolita Zabaikal'ya. In Vzaimodejstve i chronologiya kul'tur mezolita i neolita Vostochnoj Evropy. Peter the Great Museum of Anthropology and Ethnography. Russian Academy of Sciences. Sankt-Peterburg: 189-190. (in Russian)

Konstantinov M., Ekimova L., and Vereshchagin S. 2016. Tayezhnyi Chikoi na rubezhe kamnya I bronsy. Transbaikalia State University. Chita. (in Russian)

Kudo Y. 2004. Reconsidering the geochronological and archaeological framework of the late Pleistocene - early Holocene transition on the Japanese islands. In T. Terberger, B. V. Eriksen (eds.), Hunters in a changing world. Environment and archaeology of the Pleistocene - Holocene transition (ca. 11,000-9,000 B.C.) in Northern Central Europe. Internationale Archäologie: Arbeitsgemeinschaft, Symposium, Tagung, Kongress 5. Verlag Marie Leidorf GmbH. Espelkamp: 253-268.

2014. Consideration of plant use and foodstuffs cooked in Incipient Jomon potteries: A case study from the 0jiyama and Sankakuyama 1 sites, Southern Kyushu, Japan. Bulletin of the National Museum of Japanese History 187: 73-94. (in Japanese)

2015. Radiocarbon dates of the charred plant remains excavated from the Oujiyama Site, and comparison with dates of the Incipient Jomon pottery on the Southern Kyushu, Japan. Bulletin of the National Museum of 
Japanese History 196: 1-22. (in Japanese) https://doi.org/10.1016/j.quaint.2012.11.037

Kudo Y., Kumon F. 2012. Paleolithic cultures of MIS 3 to MIS 1 in relation to climat changes in the central Japanese islands. Quaternary International 248: 22-31. https://doi.org/10.1016/j.quaint.2011.02.016

Kunikita D., Shevkomud I., Onuki S., Yamshara T., and Matsuzaki H. 2013. Dating charred remains on pottery and analyzing food habits in the Early Neolithic period in Northeast Asia. Radiocarbon 55: 1334-1340. https://doi.org/10.1017/S0033822200048244

Kunikita D., Wang L., Onuki S., Sato H., and Matsuzaki H. 2017. Radiocarbon dating and dietary reconstruction of the Early Neolithic Houtaomuga snd Shuangta sites in the Song-Nen Plain, Northest China. Quaternary International 441: 62-68.

https://doi.org/10.1016/j.quaint.2017.01.031

Kuzmin Y. 2003. The paleolithic-to-Neolithic transition and the origin of pottery production in the Russian Far East: a geoarchaeological approach. Archaeology, Ethno$\log y$ \& Anthropology of Eurasia 3(15): 16-25.

2005. Geoarheologia I paleosreda pozdnego paleolita i neolita umerennogo poyasa Vostochnoi Asii. Pacific Institute of Geography. Vladivostok. (in Russian)

2006. Chronology of the earliest pottery in East Asia: progress and pitfalls. Antiquity 80: 362-371. https://doi.org/10.1017/S0003598X00093686

2013a. Origin of Old World pottery as viewed from the early 2010s: when, where and why. World Archaeology 45(4): 539-556.

https://doi.org/10.1080/00438243.2013.821669

2013b. Two trajectory in the Neolithization of Euirasia: pottery versus agriculture (Spatiotempporal patterns). Radiocarbon 55(2-3): 1304-1313.

https://doi.org/10.1017/S0033822200048219

2015. The origins of pottery in East Asia: updated analysis (the 2015 state-of-the-art). Documenta Praehistorica 42: 1-11. https://doi.org/10.4312/dp.42.1

2017. The origins of pottery in East Asia and neighboring regions: An analysis based on radiocarbon data. Quaternary International 441: 29-36.

https://doi.org/10.1016/j.quaint.2016.10.011

Kuzmin Y., Shewkomud I. 2003. The Palaeolithic-Neolithic Transition in the Russian Far East. The review of Archaeology 24(2): 37-45.
Kuzmin Y., Vetrov V. 2007. The earliest Neolithic complex in Siberia: the Ust-Karenga 12 site and its significance for the Neolithisation process in Eurasia. Documenta Praehistorica 34: 9-20. https://doi.org/10.4312/dp.34.2

Kuzmin Y., Yanshina 0., Fitzpatrick S., and Shubina 0. 2012. The Neolithic of the Kurile Islands (Russian Far East): Current State and Future Prospects. The Journal of Island and Coastal Archaeology 7(2): 234-254. https://doi.org/10.1080/15564894.2011.652762

Lapshina Z. 1999. Drevnosti ozera Khummi. Khabarovsk. (in Russian)

Lbova L., Zhambaltarova E. 2009. Kharakternye priznaki pogrebal'nogo obryada rannego neolita Zapadnogo Zabaykalia. Novosibirsk State University Bulletin. Series: History and Philology 8 (3): 89-97. (in Russian)

Lisitsin N. 1999. O Evropeisko-sibirscih kontaktah v pozdnem paleolite (About the European-Siberian contacts in the late Palaeolithic. Stratum Plus 1: 121-125. (in Russian)

Li X., Dodson J., Zhou J., and Zhou X. 2009. Increases of population and expansion of rice agriculture in Asia, and anthropogenic methane emissions since 5000 BP. Quaternary International 202: 41-50.

https://doi.org/10.1016/j.quaint.2008.02.009

Li Z., Kunikita D., and Kato S. 2017. Early pottery from the Lingjing site and the emergence of pottery in Northern China. Quaternary International 441: 49-61. https://doi.org/10.1016/j.quaint.2016.06.017

Liu L. 2005. The Chinese Neolithic: trajectories to early states. Cambridge University Press. Cambridge. https://doi.org/10.1017/CB09780511489624

2015. A long process towards agriculture in the middle Yellow river valley, China: Evidence from macro- and micro-botanical remains. Journal of Indo-Pacific Archaeo$\log y$ 35: 3-14. https://doi.org/10.7152/jipa.v35i0.14727

Liu L., Chen X. 2012. The archaeology of China: from the late Paleolithic to the Early Bronze age. Cambridge University Press. New-York.

https://doi.org/10.1017/CB09781139015301

Liu X., Hunt H., and Jones M. 2009. River valleys and foothills: Changing archaeological perceptions of North China's earliest farms. Antiquity 83(319): 82-95.

https://doi.org/10.1017/S0003598X00098100

Liu X., Fuller D., and Jones M. 2015. Early agriculture in China. In G. Barker, C. Goucher (eds.), The Cambridge World History. Cambridge University Press. Cambridge: 310-334. https://doi.org/10.1017/CB09780511978807.013 
Lu H. 2017. New methods and progress in research on the origins and evolution of prehistoric agriculture in China. Science China Earth Sciences 60: 2141-2159. https://doi.org/10.1007/s11430-017-9145-2

Lu P., Chen P., Tian Y., He Y., Moc D., Yang R., Lasaponara R., and Masini N. 2018. Reconstructing settlement evolution from neolithic to Shang dynastyin Songshan mountain area of central China based on self-organizingfeature map. Journal of Cultural Heritage 36: 23-31. https://doi.org/10.1016/j.culher.2018.08.006

Lu T. 2009. Food or Fuel? Rethinking the Exploitation of Wild Rice in South China. Paper presented at the 19th Congress of the Indo-Pacific Prehistory Association at Hanoi, Vietnam on 4 December.

2010. Early Pottery in South China. Asian Perspectives 49(1): 1-42. www.jstor.org/stable/42928771

2012. Periphery or land of cultural dynamics: rethinking prehistoric South China. Documenta Praehistorica 39: 111-135. https://doi.org/10.4312/dp.39.9

Losey R., Nomokonova T. (eds.) 2017. Holocene zooarchaeology of Gis-Baikal. Nünnerich-Asmus Verlag \& Media. Köthen.

Lucquin A. and 13 co-authors. 2016. Ancient lipids document continuity in the use of early hunter-gatherer pottery through 9,000 years of Japanese prehistory. Proceedings of the National Academy of Sciences of the USA 113(15): 3991-3996. https://doi.org/10.1073/pnas.1522908113

Makibayashi K. 2014. The Transformation of Farming Cultural Landscapes in the Neolithic Yangtze Area, China. Journal of World Prehistory 27: 295-307. https://doi.org/10.1007/s10963-014-9082-0

MacNeish R. 1999. A Paleolithic-Neolithic sequence from South China Jiangxi Province, PRC. In K. Omoto (ed.), Interdisciplinary Perspectives on the Origins of the Japanese. International Research Center for Japanese Studies. Kyoto: 233-255.

Matsumoto N., Habu J., and Matsui A. 017. Subsistence, Sedentism, and Social Complexity among Jomon Hunter-Gatherers of the Japanese Archipelago. In J. Habu, P. Lape, and J. Olsen (eds.), Handbook of East and Southeast Asian Archaeology. Springer Science+Business Media, LLC. New-York: 437-450.

https://doi.org/10.1007/978-1-4939-6521-2_27

Mizoguchi K. 2002. An archaeological history of Japan: 30000 bc to ad 700. University of Pennsylvania Press. Philadelphia (PA).
Morgan C., Tushingham S., Garvey R., Barton L., and Bettinger R. 2017. Hunter-Gatherer Economies in the Old World and New World. In Oxford Research Encyclopedia of Environmental Science. Oxford University Press. Oxford: 17-43.

Morisaki K., Izuho M., Terry K., and Sato H. 2015. Lithics and climate: technological responses to landscape change in Upper Palaeolithic northern Japan. Antiquity 89: 554572. https://doi.org/10.15184/aqy.2015.23

Morisaki K., Izuho M., and Sato H. 2018. Human Adaptive Responses to Environmental Change During the Pleistocene-Holocene Transition in the Japanese Archipelago. In E. Robinson, F. Sellet (eds.), Lithic Technological Organization and Paleoenvironmental Change. Studies in $\mathrm{Hu}-$ man Ecology and Adaptation 9. Springer International Publishing AG. Cham: 91-120.

https://doi.org/10.1007/978-3-319-64407-3_6

Morisaki K., Sato H. 2014. Lithic technological and human behavioral diversity before and during the Late Glacial: A Japanese case study. Quaternary International 347: 200210. https://doi.org/10.1016/j.quaint.2014.04.021

Morisaki K., Natsuki D. 2017. Human behavioral change and the distributional dynamics of early Japanese pottery. Quaternary Internatioal 441: 12-28.

https://doi.org/10.1016/j.quaint.2016.09.040

Morisaki K., Kunikita D., and Sato H. 2018. Holocene climatic fluctuation and lithic technological change in northeastern Hokkaido (Japan). Journal of Archaeological Science: Reports 17: 1018-1024.

http://dx.doi.org/10.1016/j.jasrep.2016.04.011

Moroz P. 2014a. Kamennye industrii rubezha pleistocena I golocena Zapadnogo Zabaikalia. Transbaikalia State University. Chita. (in Russian)

2014b. Cyr'evoy factor v verhnem I final'nom paleolite Zabaikalia. In Problemy arheologii kamnya: $k$ 70letiyu V. I. Belyaevoy. St.-Petersburg University. St. Peterburg: 15-26. (in Russian)

Nakazawa Y., Izuho M., Takakura J., and Yamada S. 2005. Toward an understanding of technological variability in microblade assemblages in Hokkaido, Japan. Asian Perspectives 44 (2): 276-290.

Nakazawa Y., Iwase A., Akai F., and Izuho M. 2011. Human responses to the Younger Dryas in Japan. Quaternary International 242: 416-433.

https://doi.org/10.1016/j.quaint.2010.12.026

National Museum of Japanese History (eds.) 2009. Beginning of the Jomon Culture: what took place in 15000 
years ago? National Museum of Japanese History, Tokyo. (in Japanese)

Nishida M. 2002. Another Neolithic in Holocene Japan. Documenta Praehistorica 39: 21-28.

https://doi.org/10.4312/dp.29.2

Nordqvist K., Kriiska A. 2015. Towards Neolithisation: The Mesolithic-Neolithic transition in the central area of the eastern part of the Baltic Sea. In J. Kabaciński, S. Hartz, D. C. M. Raemaekers, and T. Terberger (ed.), The Dabki Site in Pomerania and the Neolithisation of the North European Lowlands (c. 5000-3000 cal BC). Archäologie und Geschichte im Ostseeraum. Rahden/Westf. Leidorf: 537-556.

Noshiro S., Kudo Y., and Sasaski Y. 2016. Emergence of prehistoric management of plant resource during the Incipient to initial Jomon periods in Japan. Quaternary International 426: 175-186.

https://doi.org/10.1016/j.quaint.2016.04.004

Obihiro City Board of Education (eds.) 2005. Obihiro Taisho sites 1. Obihiro City Board of Education. Obihiro. (in Japanese).

Otsuka Y. 2017. The background of transition in microblade industries in Hokkaido, northern Japan. Quaternary International 442: 33-42.

https://doi.org/10.1016/j.quaint.2016.07.023

Özdoğan M. 2010. Westward expansion of the Neolithic way of life: Sorting the Neolithic package into distinct packages. In P. Matthiae, F. Pinnock, L. Nigro, and N. MarAchetti (eds.), Near Eastern Archaeology in the Past, Present and Future. Heritage and Identity. Proceedings of the 6th ICAANE. Harrassowitz Verlag. Wiesbaden: 883-897.

2014. A new look at the introduction of the Neolithic way of life in Southeastern Europe. Changing paradigms of the expansion of the Neolithic way of life. Documenta Praehistorica 41: 33-49.

https://doi.org/10.4312/dp.41.2

Pan Y., Zheng Y., and Chen C. 2017. Human ecology of the early Neolithic Kuahuqiao Culture in East Asia. In J. Habu, P. Lape, and J. Olsen (eds.), Handbook of East and Southeast Asian Archaeology. Springer Science+Business Media LLC. New-York: 347-378.

Pavlenok G. 2015. Technologiya obrabotki kamnya v selenginskoy kul'ture Zapadnogo Zabaikalya/po materialam stoyanki Ust'-Kyahta 3/(Stone industry of the Selenga culture/on the materials of the Ust'-Kyakhta 3 site/. Unpublished PhD dissertation Institute of Archaeology and Ethnography. Siberian Branch of Russian Academy of Sciences. Novosibirsk. (in Russian)
Pearson R., 2006. Jomon hot spot: increasing sedentism in south-western Japan in the Incipient Jomon $(14,000$ 9250 cal. BC) and Earliest Jomon (9250-5300 cal. BC) periods. World Archaeology 38: 239-258.

www.jstor.org/stable/40024499

Philatov E. 2016. Sukhotinskiy geoarheologicheskiy komplex (Sukhotino Geoarchaeological complex). Transbaikalia State University. Chita. (in Russian)

Prendergast M., Yuan J., and Bar-Yosef 0. 2009. Resource intensification in the Late Upper Paleolithic: a view from southern China. Journal of Archaeological Science 36: 1027-1037. https://doi.org/10.1016/j.jas.2008.12.002

Razgil'deeva I., Reshetova S., and Popov V. 2010. New data of Studenoye 1 site study (on the problem of age of cultural layers). In Y. Lee, N. Drozdov (eds.), The XIIth International Symposium Suyanggae and her neighbours. Prehistoric migrations in Eurasia and Amirica: collected work. State Pedagogical University. Krasnoyarsk: 162-167.

Razgil'deeva I., Kunikita D., and Yanshina 0. 2013. Novye dannye o vozraste drevneishih keramicheskih kompleksov Zapadnogo Zabaikalia In Evrazia v Kaynozoe. Stratigraphia. Paleoekologia. Kultury. Irkutsk State University. Irkutsk: 168-178. (in Russian)

Ren G. 2007. Changes in forest cover in China during the Holocene. Vegetation History and Archaeoboty 16: 119126. https://doi.org/10.1007/s00334-006-0075-5

Rice P. 1999. On the origins of pottery. Journal of $A r$ chaeological Method and Theory 6: 1-54.

www.jstor.org/stable/20177395

Rogovskoy E., Kuznetsov A. 2013. Rybolovstvo v rannem holocene na mnogosloinom mestona-hozhdenii Ostrov Listvenichnyi (V zone zatopleniya Boguchanskoy GES). Izvestiya Irkutskogo Gosudarstvennogo universiteta. Seriya Geoarheologiya, Etnologiya, Antropologiya 2(3): 15-32. (in Russian)

Roosevelt A. 1995. Early pottery in the Amazon: Twenty years of scolarly obscurity. In W. Barnett, J. Hoppes (eds.), The emergence of pottery: Technology and innovation in Ancient Societies. Smithsonian Institution Press. Washington and London: 115-131.

Sato H., Izuho M., and Morisaki K. 2011. Human cultures and environmental changes in the Pleistocene-Holocene transition in the Japanese Archipelago. Quaternary International 237: 93-102.

https://doi.org/10.1016/j.quaint.2011.01.006

Sato H., Tsutsumi T. 2007. The Japanese microblade industries: Technology, raw material procurement, and adapta- 
tions. In Y. Kuzmin, S. Keates, and S. Chen (eds.). Origin and Spread of Microblade Technology in Northern Asia and North America. Archaeology Press. Burnaby: 53-78.

Sato H., Natsuki D. 2017. Human behavioral responses to environmental condition and the emergence of the world's oldest pottery in East and Northeast Asia: an overview. Quaternary International 441: 12-28.

https://doi.org/10.1016/j.quaint.2016.12.046

Seguchi S. 2014. Landscape 'Neolithization' among the hunter-fisher-gatherers of lake Biwa, central Japan. Journal of World Prehistory 27: 225-245.

https://doi.org/10.1007/s10963-014-9078-9

Shelach-Lavi G. 2015. The Archaeology of Early China: From Prehistory to the Han Dynasty. Cambridge University Press. New-York.

https://doi.org/10.1017/CB09781139022682

Shewkomud I., Kuzmin Y. 2009. Khronologiya kamennogo veka Nizhnego Priamurya (Dalniy Vostok Rossii). In I. Shewkomud (ed.) Cultural chronology and other problems within Ancient East Asia study. Kabarovsky Regional Museum. Khabarovsk: 7-47. (in Russian)

Shewkomud I., Yanshina 0. 2010a. Nachalo neolita v Priamurye: osipovskaya kultura. In A. Derevyanko, A. Vasilevskiy (eds.), Mezhdunarodny simpozium "Pervonachalnoye osvoeniye chelovekom kontinentalnoy sushi i ostrovnoy chasti Severo-Vostoka Azii”. Sakhalin State University. Yuzhno-Sakhalinsk: 118-134. (in Russian).

2010b. Perekhod ot paleolita k neolitu v Priamurye: obzor osnovnykh komplexov i nekotoryie problemy. In N. Kluev, Y. Vostretsov (eds.), Lifting the veil of millennia: for the 80th birthday of J. V. Andreeva: collection of scientific papers. Reya. Vladivostok: 50-72 (in Russian)

2012. Nachalo neolita v Priamurye: Goncharka-1 site. Peter the Great Museum of Anthropology and Ethnography. Russian Academy of Sciences. St.-Petersburg. (in Russian with English summary).

Shinto K. 2006. Jomon Culture in Kagoshima and Uenohara Site. Journal of Temporal design in architecture and the environment 6(2): 59-63.

http://www.jtdweb.org/

Shibutani A. 2009. Late Pleistocene to Early Holocene plant movements in Southern Kyushu, Japan. Archaeologies: Journal of the World Archaeological Congress 5(1): 124-133. https://doi.org/10.1007/s11759-009-9094-Z

2011. Starch on stone tools at the Nishitaragasako site, Kagoshima, Japan, and its plant utilization in the Upper Palaeolithic period. Bulletin of the Hiroshima University Museum 3: 73-88.
Smith B. 2001. Low-level food production. Journal of Archaeological Research 9(1): 1-43.

Stevens C., Fuller D. 2017. The spread of agriculture in eastern Asia. Archaeological bases for hypothetical farmer/ language dispersals. Language Dynamics and Change 7: 152-186. https://doi.org/10.1163/22105832-00702001

Sun B., Wagner M., Zhao Z., Li G., Wu X., and Tarasov P. 2014. Archaeological discovery and research at Bianbiandong early Neolithic cave site, Shandong, China. Quaternary International 348: 169-182.

https://doi.org/10.1016/j.quaint.2014.06.013

Tabarev A., Gladyshev S. 2012. Rannegolotsenovye microplastinchatye industrii Tsentral'noi Azii (po materialam kitaisko-shvedskoi ekspeditsii S. Khedina, Musei Vostochnyh drevnostei, Stokgolm, Shvet-sia). Vestnik Novosibirskogo Gosudarstvennogo Universiteta. Seria Istoriya. Philosophiya 11(3): 222-232. (in Russian)

Tashak V. 2005. Paleoliticheskie i mezoliticheskie pamyatniki Ust'-Kyahty. Ulan-Ude. (in Russian)

Teten'kin A. 2010. Materialy issledovaniy ansamblya arheologicheskih mestonahozhdeniy Kovrizhka na Nizhnem Vitime (1995-2009). Reports of the Laboratory of ancient technology 1(8): 64-134. (in Russian)

Tsydenova N., Piezonka H. 2015. The transition from the Late paleolithic to the Initial Neolithic in the Baikal region: technological aspects of stone industries. Quaternary International 355: 101-113.

https://doi.org/10.1016/j.quaint.2014.07.070

Tsydenova N., Andreeva D., and Zech W. 2017. Early pottery in Transbaikal Siberia: new data from Krasnaya Gorka. Quaternary International 441: 81-90.

https://doi.org/10.1016/j.quaint.2017.01.035

Uchiyama J., Gillam J. C., Hosoya L. A., Lindstrom K., and Jordan P. 2014. Investigating Neolithization of cultural landscapes in East Asia: the NEOMAP project. Journal of World Prehistory 27: 197-223.

https://doi.org/10.1007/s10963-014-9079-8

Vasil'yevsky R., Krupyanko A., and Tabarev A. 1997. Genezis neolita na yuge Dalnego Vostoka Rossii. Far East State University. Vladivostok. (in Russian)

Vasilevsky A. 2008. Kamennyi vek ostrova Sakhalin. Sakhalin book publisher. Yuzhno-Sakhalinsk. (in Russian)

Vasilevsky A., Shubina 0. 2006. Neolithic of the Sakhalin and Southern Kurile Islands. In S. Nelson, A. Derevyanko, Y. Kuzmin, and R. Bland (eds.), Archaeology of the Russian Far East: Essays in stone age prehistory. British Archaeological Reports IS 1540. Archaeopress. Oxford: 151- 166. 
Vetrov V. 2010. Drevnejshaya reramika na Vitime: Nekotorye voprosy datirovaniya I periodizatsii v kamennom veke Vostochnoy Azii. In Drevnie kul'tury Mongolii i Bajkalskoj Sibiri: Arheologiya i sovremmenost'. BGU. UlanUde: 37-44. (in Russian)

Wagner M. 2006. Neolithikum und frühe Bronzezeit in Nordchina vor 8000 bis 3500 Jahren - Die nordöstliche Tiefebene - Südteil. Archäologie in Eurasien, Band 21. Verlag Philipp von Zabern. Mainz.

Wagner M., Tarasov P. 2014. The Neolithic of Northern and Central China. In C. Renfrew, P. Bahn (eds.), The Cambridge World Prehistory. Cambridge University Press. Cambridge: 742-764.

https://doi.org/10.1017/CH09781139017831.052

Wang C., Lu H., Zhang J., He K., and Huan X. 2016. Macroprocess of past plant subsistence from the Upper Paleolithic to Middle Neolithic in China: A quantitative analysis of multi-archaeobotanical data. PLOS ONE 11(2): e0148136. https://doi.org/10.1371/journal.pone.0148136

Wang L., Sebillaud P. 2019. The emergence of early pottery in East Asia: New discoveries and perspectives. Journal of World prehistory 32(1): 73-110.

https://doi.org/10.1007/s10963-018-9126-y

Weiss E., Wetterstrom W., Nadel D., and Bar-Yosef 0. 2004. The broad spectrum revisited: Evidence from plant remains. Proceedings of the National Academy of Sciences of the USA 101(26): 9551-9555.

www.pnas.org_cgi_doi_10.1073_pnas.0402362101

Wu L., Zhu C., Zheng C., Ma C., Wang X., Li F., Li B., and Li K. 2014. Impact of Holocene climate change on the prehistoric cultures of Zhejiang region, East China. Journal of Geographical sciences 24(4): 669-688. https://doi.org/10.1007/s11442-014-1112-4

Wu R., Deng Z., Zhang Z., Li J., Peng S., and Liu S. 2005. Scientific research on the pottery unearthed from the Xianrendong site in Wanian, Jangxi. Kao Gu Xue Bao 7: 542-549. (in Chinese).

Wu W., Wang X., Wu X., Jin G., and Tarasov P. 2014. The early Holocene archaeobotanical record from the Zhangmatun site situated at the northern edge of the Shandong Highlands, China. Quaternary International 348: 183193. https://doi.org/10.1016/j.quaint.2014.02.008

Wu X., Chi Z., Goldberg, P., Cohen, D., Pan Y., Arpin T., and Bar-Yosef 0. 2012. Early pottery at 20,000 years ago in Xianrendong cave, China. Science 336: 1696-1700. https://doi.org/10.1126/science.1218643
Yang X. and 12 co-authors. 2012. Early millet use in northern China. Proceedings of the National Academy of Sciences of the USA 109(10): 3726-3730.

https://doi.org/10.1073/pnas.1115430109

Yang X., Ma Z., Li J., Yu J., Stevens C., and Zhuang Y. 2015. Comparing subsistence strategies in different landscapes of North China 10,000 years ago. The Holocene 25 (12): 1957-1964.

https://doi.org/10.1177/0959683615596833

Yang X., Ma Z., Wang T., Perry L., Li Q., Huan X., and Yu J. 2014. Starch grain evidence reveals early pottery function cooking plant foods in North China. Chinese Science Bulletin 59(32): 4352-4358.

https://doi.org/10.1007/s11434-014-0500-6

Yang S., Zhang Y., Li Y., Zhao C., Li X., Yue J., Hou Y., Deng C., Zhu R., and Petraglia M. 2017. Environmental change and raw material selection strategies at Taoshan: a terminal Late Pleistocene to Holocene site in north-eastern China. Journal of Quaternary science 32(5): 553563. https://doi.org/10.1002/jqs.2950

Yanshina 0. 2008. Perekhod ot paleolita k neolitu v basseine Yponskogo morya: otkrytiya, facty, gipotezy. In G. Khlopachev (ed.), Chronolologiya, Periodizatsiya i crosscultural svyazi v kamennom veke. Peter the Great $\mathrm{Mu}-$ seum of Anthropology and Ethnography. Russian Academy of Sciences. Sankt-Peterburg: 134-147. (in Russian)

2014. Ponyatie neolit i arkheologiya Vostochnoy Azii. Rossiyskiy arkheologicheskiy ezhegodnik 4: 125-152. (in Russian)

2017. The earliest pottery of eastern part of Asia: similarities and differences. Quaternary International 441: 69-81. https://doi.org/10.1016/j.quaint.2016.10.035

Yanshina 0., Sobolev A. 2018. The earliest pottery of Xianrendong cave: what do we know about it? Journal of ancient technology laboratory 14(3): 9-21.

https://doi.org/10.21285/2415-8739-2018-3-9-21

Zhushchikhovskaya I. 2006. Neolithic of the Primorye. In S. Nelson, A. Derevyanko, Y. Kuzmin, and R. Bland (eds.), Archaeology of the Russian Far East: Essays in stone age prehistory. British Archaeological Reports IS 1540. Archaeopress. Oxford: 123-149.

Zeder M. 2009. The Neolithic macro-(r)evolution: macroevolutionary theory and the study of culture change. Journal of Archaeological Research 17: 1-63.

https://doi.org/10.1007/s10814-008-9025-3 
2011. The origin of agriculture in the Near East. Current Anthropology 52(4): S221-S235.

https://www.jstor.org/stable/10.1086/659307

Zhang C., Hung H. 2010. The emergence of agriculture in southern China. Antiquity 84: 11-25.

https://doi.org/10.1017/S0003598X00099737

2013. Eastern Asia: archaeology. In The encyclopedia of global human migration. Blackwell Publishing. 0xford: 209-216.

https://doi.org/10.1002/9781444351071.wbeghm826

Zhao Z. 1998. The middle Yangtze region in China is one place where rice was domesticated: phytolith evidence from the Diaotonghuan cave, northern Jiangxi. Antiquity 72 : 885-897. https://doi.org/10.1017/S0003598X00087524
2011. New archaeobotanic data for the study of the origins of agriculture in China. Current Anthropology 52 (4): $\$ 295-S 306$.

https://www.jstor.org/stable/10.1086/659308

Zhuang Y. 2015. Neolithisation in North China: Landscape and geoarchaeological perspectives. Environmental Archaeology 20(3): 251-264.

https://doi.org/10.1179/1749631414Y.0000000047

Zou G., Shelach G., Li X., Zhao C., Rui X., Zhou L., and Zhang J. 2018. Geochronology and paleoenvironment of the Taoshan site, northeastern China, and archaeological implications. Quaternary International 463A: 6-17. https://doi.org/10.1016/j.quaint.2017.06.073

\section{back to contents}

